\title{
Metal-containing peptide nucleic acid conjugates
}

Gasser, Gilles ; Sosniak, Anna M ; Metzler-Nolte, Nils

\begin{abstract}
Peptide Nucleic Acids (PNAs) are non-natural DNA/RNA analogues with favourable physicochemical properties and promising applications. Discovered nearly 20 years ago, PNAs have recently re-gained quite a lot of attention. In this Perspective article, we discuss the latest advances on the preparation and utilisation of PNA monomers and oligomers containing metal complexes. These metalconjugates have found applications in various research fields such as in the sequence-specific detection of nucleic acids, in the hydrolysis of nucleic acids and peptides, as radioactive probes or as modulators of PNA DNA hybrid stability, and last but not least as probes for molecular and cell biology.
\end{abstract}

DOI: https://doi.org/10.1039/C0DT01706J

Posted at the Zurich Open Repository and Archive, University of Zurich ZORA URL: https://doi.org/10.5167/uzh-60259

Journal Article

Accepted Version

Originally published at:

Gasser, Gilles; Sosniak, Anna M; Metzler-Nolte, Nils (2011). Metal-containing peptide nucleic acid conjugates. Dalton Transactions, 40(27):7061-7076.

DOI: https://doi.org/10.1039/C0DT01706J 


\title{
Metal-Containing Peptide Nucleic Acid Conjugates
}

\author{
Gilles Gasser, ${ }^{a^{*}}$ Anna M. Sosniak ${ }^{b}$ and Nils Metzler-Nolte ${ }^{b^{*}}$
}

anstitute of Inorganic Chemistry, University of Zurich, Winterthurerstrasse 190, CH-8057 Zurich, Switzerland; ${ }^{b}$ Department of Inorganic Chemistry I - Bioinorganic Chemistry, Faculty of Chemistry and Biochemistry, Ruhr-University Bochum, Universitätsstrasse 150, 44801 Bochum, Germany.

RECEIVED DATE (to be automatically inserted after your manuscript is accepted if required according to the journal that you are submitting your paper to)

${ }^{*}$ Corresponding authors.

Email: gilles.gasser@aci.unizh.ch. Phone: +41 (0)44 63546 11. Fax: +41 (0)44 63546 11. WWW: www.gassergroup.com

Email: nils.metzler-nolte@,rub.de. Phone: +49 (0)234 - 32 28152; Fax: +49 (0)234 - 32 14378. WWW: $\underline{\text { www.rub.de/ac1 }}$

Keywords: Bioconjugates, Bioinorganic Chemistry, Bioorganometallics, Biosensor, Medicinal Inorganic Chemistry, Peptide Nucleic Acids. 


\begin{abstract}
.
Peptide Nucleic Acids (PNAs) are non-natural DNA/RNA analogues with favourable physicochemical properties and promising applications. Discovered nearly 20 years ago, PNAs have recently re-gained quite a lot of attention. In this perspective article, we discuss the latest advances on the preparation and utilisation of PNA monomers and oligomers containing metal complexes. These metalconjugates have found applications in various research fields such as in the sequence-specific detection of nucleic acids, in the hydrolysis of nucleic acids and peptides, as radioactive probes or as modulators of PNA •DNA hybrid stability.
\end{abstract}


Gilles Gasser completed his $\mathrm{PhD}$ thesis on supramolecular chemistry in 2004 at the University of Neuchâtel (Switzerland) under the guidance of Prof. Helen Stoeckli-Evans, in close collaboration with Dr. James Tucker from the University of Exeter, UK (now at the University of Birmingham). From 2004-2007, endowed with a Swiss National Science Foundation (SNSF) grant for prospective researchers, Gilles carried out a post-doc on bioinorganic chemistry with Prof. Leone Spiccia (Monash University, Melbourne, Australia) before being awarded an Alexander von Humboldt Research Fellowship in 2007 that he undertook at the Ruhr-University Bochum (Germany) in the group of Prof. Nils Metzler-Nolte. In 2010, Gilles started his independent research group at the Institute of Inorganic Chemistry of the University of Zurich (Switzerland) as a SNSF Ambizione research fellow. Since March 2011, Gilles is a SNSF assistant professor in the same institution. His current research interests cover various fields of inorganic chemical biology and medicinal inorganic chemistry, focusing in using metal complexes to modulate the properties of biomolecules.

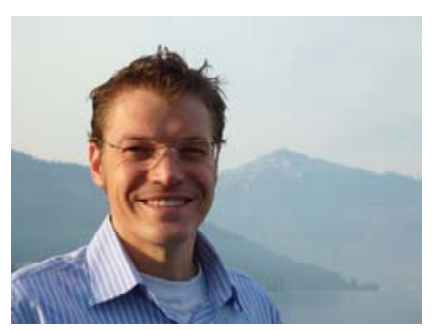

Anna Sosniak studied biochemistry at the Ruhr-University Bochum and completed her Master thesis on the thermal stability studies of modified PNA DNA hybrids, as well as the enzymatic recognition and modification of single-mismatched PNA •DNA hybrids in 2007 at the Ruhr-University Bochum under the guidance of Prof. Gilles Gasser and Prof. Nils Metzler-Nolte. Thereafter, she started her PhD thesis on the application of metal-containing PNA bioconjugates in antisense therapy in the same institution as a Research School Bochum fellow. 


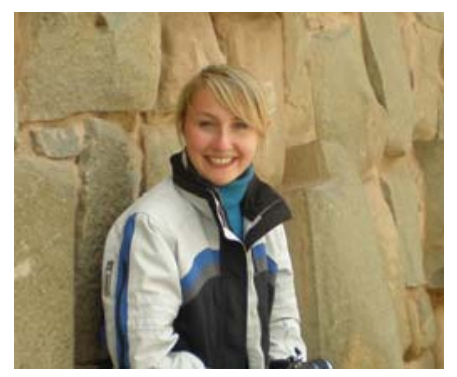

Nils Metzler-Nolte studied chemistry at the Universities of Hamburg, Freiburg, and Munich. He graduated in 1992 and obtained a PhD with Prof. H. Nöth from the Ludwig-Maximilians-Universität Munich in 1994. After a postdoc with Prof. M. L. H. Green in Oxford he started his independent research on Bioorganometallic Chemistry at the Max-Planck-Institut für Strahlenchemie (nowadays MPI for Bioinorganic Chemistry) in Mülheim in 1996. He was appointed professor for pharmaceutical and bioinorganic chemistry at the University of Heidelberg's Institute for Pharmacy and Molecular Biotechnology in 2000, and accepted an offer as full professor of Inorganic Chemistry at the RuhrUniversity of Bochum in 2006. Here, he was elected Dean of the University-wide graduate school (RUB Research School) in 2009 and currently serves as Vice President (Prorektor) for early career researchers and international affairs for the University. Nils has received several fellowships and awards for his work. He is Speaker of the DFG-funded Research Unit "Biological Function of Organometallic Compounds", Steering Committee member of the COST action D39 "Metallodrug Design and Action", and serves as an international advisory board member of several journals, among them Chemical Science and Dalton Transactions. He has organized the $5^{\text {th }}$ International Symposium on Bioorganometallic Chemistry in July 2010 in Bochum (ISBOMC'10). With research interests including model systems for bioorganometallic enzymes, medicinal organometallic chemistry, functional metal bioconjugates, and most recently biocompatible nanoparticles, the group is running the full program of inorganic and organic chemical synthesis and characterization through to cell culture and biological investigations. 


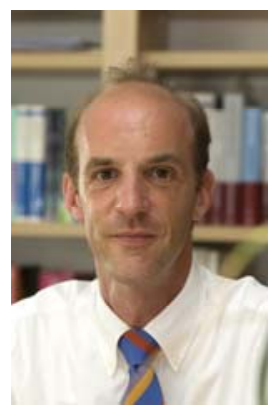




\section{Introduction.}

Peptide nucleic acids (PNAs) are non-natural nucleic acid analogues. ${ }^{1,2}$ Their neutral pseudopeptide backbone is made of $\mathrm{N}$-(2-aminoethyl)glycine units which are ligated via a methylene carbonyl to the four nucleobases (Figure 1). ${ }^{1}$ Single-stranded (ss) PNAs bind to complementary ssDNA, ${ }^{1,3}$ RNA $^{3}$ or $\mathrm{PNA}^{4}$ sequences obeying the Watson-Crick base-pairing rules. Hybridisation may occur in a parallel, or more favourably, in an antiparallel fashion. In this case, the $N$-terminus of the PNA faces the 3 '- end of the nucleic acid oligomer. ${ }^{5}$ In comparison to double-stranded DNA (dsDNA), corresponding PNA $•$ DNA hybrids are thermally more stable due to the absence of electrostatic repulsion between the strands. Moreover, PNA is much more mismatch sensitive than DNA, enabling sensitive and selective mismatch discrimination. All these favourable features have allowed PNAs to be applied to various research areas such as antisense $\mathrm{e}^{6-8}$ and antigene $\mathrm{e}^{9-11}$ therapies (see Figure 2 for a schematic representation), biosensing ${ }^{12}$ and in the high-throughput screening of enzymes using a PNA library. ${ }^{13}$

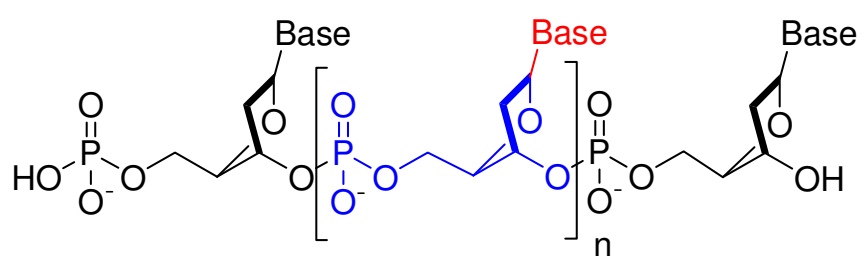

DNA

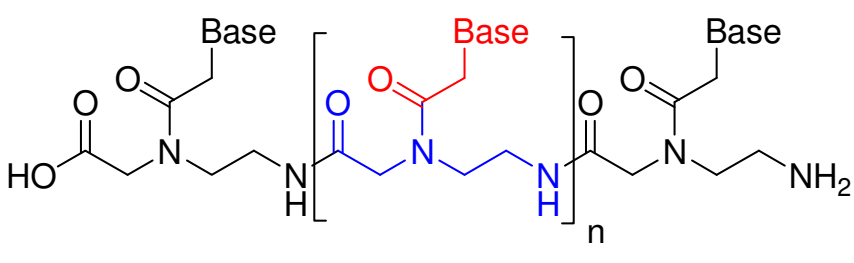

PNA

Figure 1. Structure comparison between DNA and PNA. 

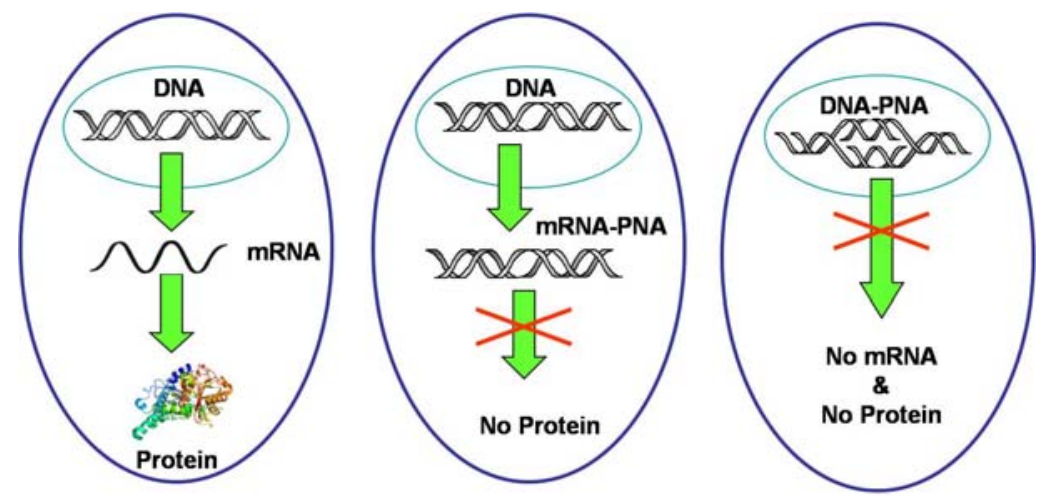

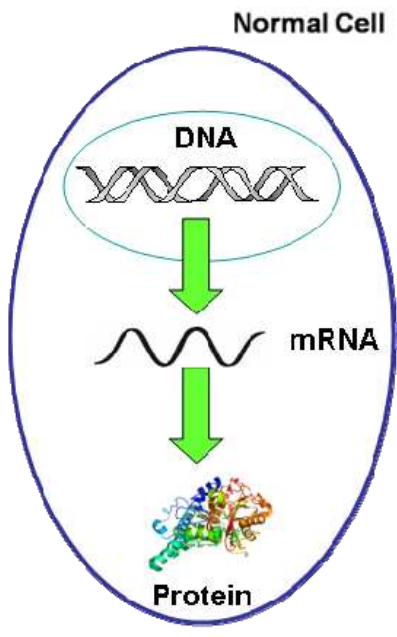

Normal Cell

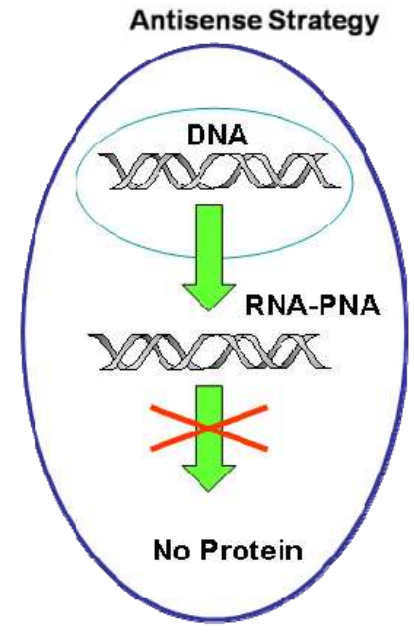

Antlsense Strategy

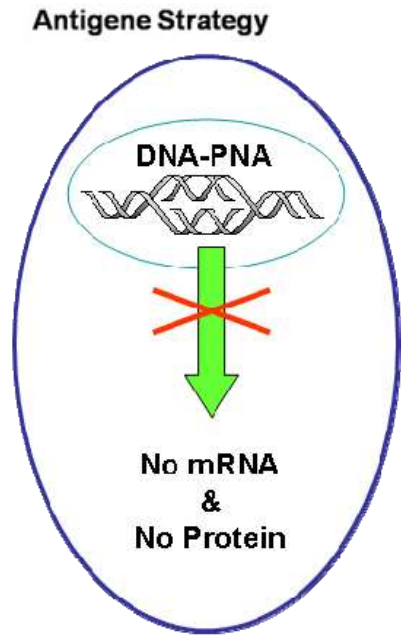

Antlgene Strategy

Figure 2. Schematic representation of the antisense and antigene strategies.

In order to modify the intrinsic properties of PNAs or in order to add new functionalities and/or spectroscopic properties to PNA oligomers, metal complexes have been synthetically attached to these non-natural DNA analogues. ${ }^{14-16}$ In this perspective article, we are reporting on the recent advances in both the preparation and use of metal-containing PNAs. In particular, we are dealing only with PNA bioconjugates with covalently bound metal complexes. 


\section{Metal-containing PNAs for biosensing purposes.}

The detection of specific DNA sequences on the basis of hybridization is realisable rapidly and economically by DNA biosensors. DNA biosensors probe and/or detect the hybridization event, which is then transduced, for example, into an electrochemical ${ }^{17-22}$ or optical $^{23-26}$ signal (Figure 3). In principle, an analytical sample, which contains, amongst others, the DNA sequence-of-interest (the target), is deposited onto the recognition layer of a transducer. The recognition layer is composed of an immobilized single-stranded nucleic acid (analogue) strand, which is the capture probe for the complementary target sequence.

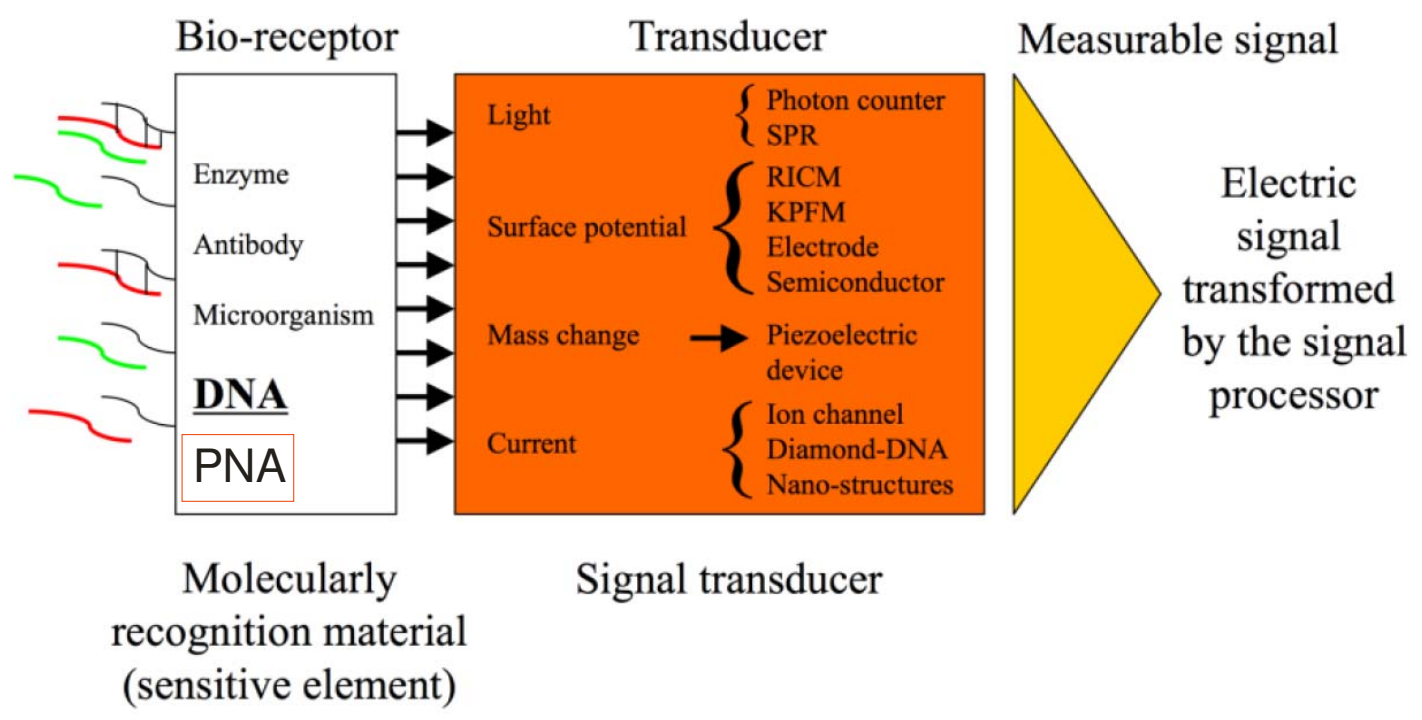

Figure 3. Scheme of a biosensor. Figure reproduced with permission of the publisher from ref. ${ }^{27}$

Due to the favourable hybridisation properties of PNAs (higher thermal duplex stability and mismatch discrimination), DNA biosensors with PNA recognition layers have been developed. ${ }^{28}$ PNA-derived biosensors are able to distinguish closely related sequences under less restrictive reaction conditions than for DNA. Notably, higher temperatures, solutions with low ionic strength and shorter sequences can be employed. ${ }^{29,}{ }^{30}$ Electrochemical DNA detection is facilitated by redox-active probes, which are 
introduced into the PNA recognition layer as free-diffusing redox mediator, ${ }^{31}$ redox-active intercalators or minor-groove binders ${ }^{28,} 32-35$ or as covalently bound redox labels. ${ }^{36-39}$ Label-free PNA-based biosensors were, in general, exploited using electrochemical impedance spectroscopy, ${ }^{31,40,41}$ Scanning Electrochemical Microscope (SECM) ${ }^{42}$ reflection absorption infrared spectroscopy (RAIRS) or X-ray photoelectron spectroscopy (XPS) as detection techniques. ${ }^{43,44}$

The covalent insertion of metals into the PNA capture probe seems an interesting alternative to avoid the addition of indicators. The main advantages of such an alternative are the distinct and permanent label-strand bonding and the certainty about the location and the strand bonding of the probe. For this purpose, redox-active moieties, namely ferrocene carboxylic acid and ruthenium complexes, were first conjugated on the $N$-terminus of thymine PNA monomers and PNA oligomers by Metzler-Nolte et al. ${ }^{45-}$ ${ }^{47}$ For potential insertion of organometallic moieties within the PNA sequence, Hudson et al. used solution-phase and solid-phase Sonogashira coupling to modify uracil-PNA monomers with ferrocene alkynes. ${ }^{48}$ Chromiumtricarbonyl thymine PNA monomers as well as PNA dimers were synthesised by Baldoli and Maiorana via the Ugi reaction. ${ }^{49,} 50$ The same authors have also reported a PNA monomer labeled with Fischer-type carbene complexes, ${ }^{51}$ as well as an 8-mer PNA oligomer, which contains a Fischer-type carbene complex of tungsten. ${ }^{52}$ For better sensitivity, thymine PNA monomers with multiple, e.g. three, and electrochemically equivalent ferrocene moieties were synthesised. ${ }^{53}$ Nevertheless, to the best of our knowledge, no successful insertion of these modified monomers into PNA oligomers were reported so far. Gasser, Spiccia and coworkers reported the synthesis of ferrocenyl uracil PNA monomers. ${ }^{54}, 55$ In a new synthetic strategy, an alkyne-containing PNA monomer was synthesised as a building block for subsequent metal derivatisation by the copper(I)-catalysed Huisgen 1,3-dipolar cycloaddition reaction of azides and terminal alkynes ( $\mathrm{Cu}-\mathrm{AAC})$. This reaction is the best known out of the class of reactions named under the general term, "click chemistry". ${ }^{56} \mathrm{Cu}-\mathrm{AAC}$ takes place under mild reaction conditions, with high yields and its products, namely, 1,4-disubstituted 1,2,3triazole derivatives, are stable. Furthermore, the $\mathrm{Cu}$-AAC is consistent with solid phase synthesis 
protocols, which means that the insertion of metal moieties is realizable on the solid phase. ${ }^{57}$ Therefore, the alkyne-substituted PNA monomer (1, Figure 4) was synthesised as a building block and could be inserted into a PNA sequence at any desired position by solid phase peptide synthesis (SPPS). ${ }^{57}$ In $\mathbf{1}$, the nucleobase is completely replaced by the alkyne moiety while the PNA backbone remains. The "click" reaction with azido-ferrocene was carried out on the solid phase to give the "clicked" ferrocenyl-PNA conjugate.
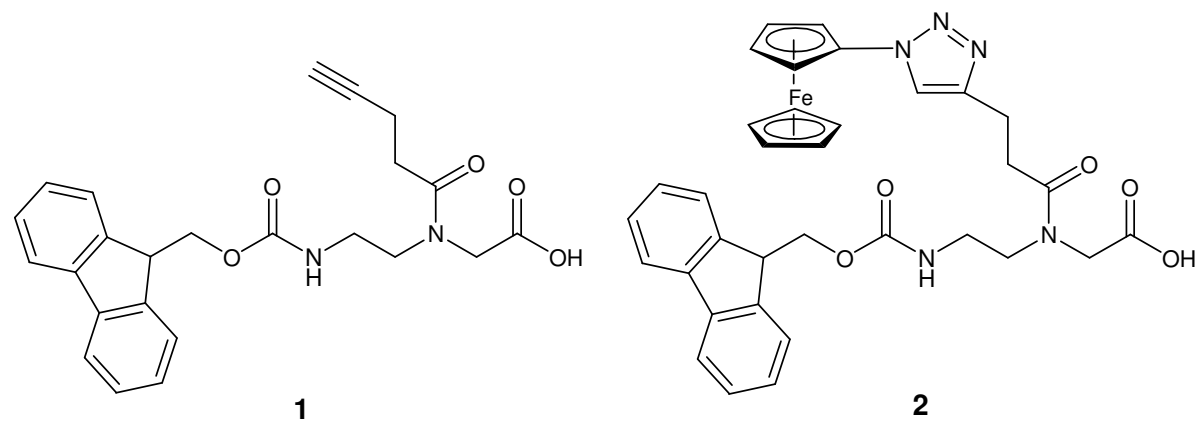

Figure 4. Modified PNA monomer 1 (left) and 2 (right).

In a further step, various ferrocene "clicked" PNA oligomers were reported and their electrochemical properties were analyzed. ${ }^{58}$ The application of different ferrocenyl starting materials resulted in a library of ferrocenyl PNA oligomers with different electrochemical potentials using the same chemistry (Figure 5). ${ }^{58}$ 


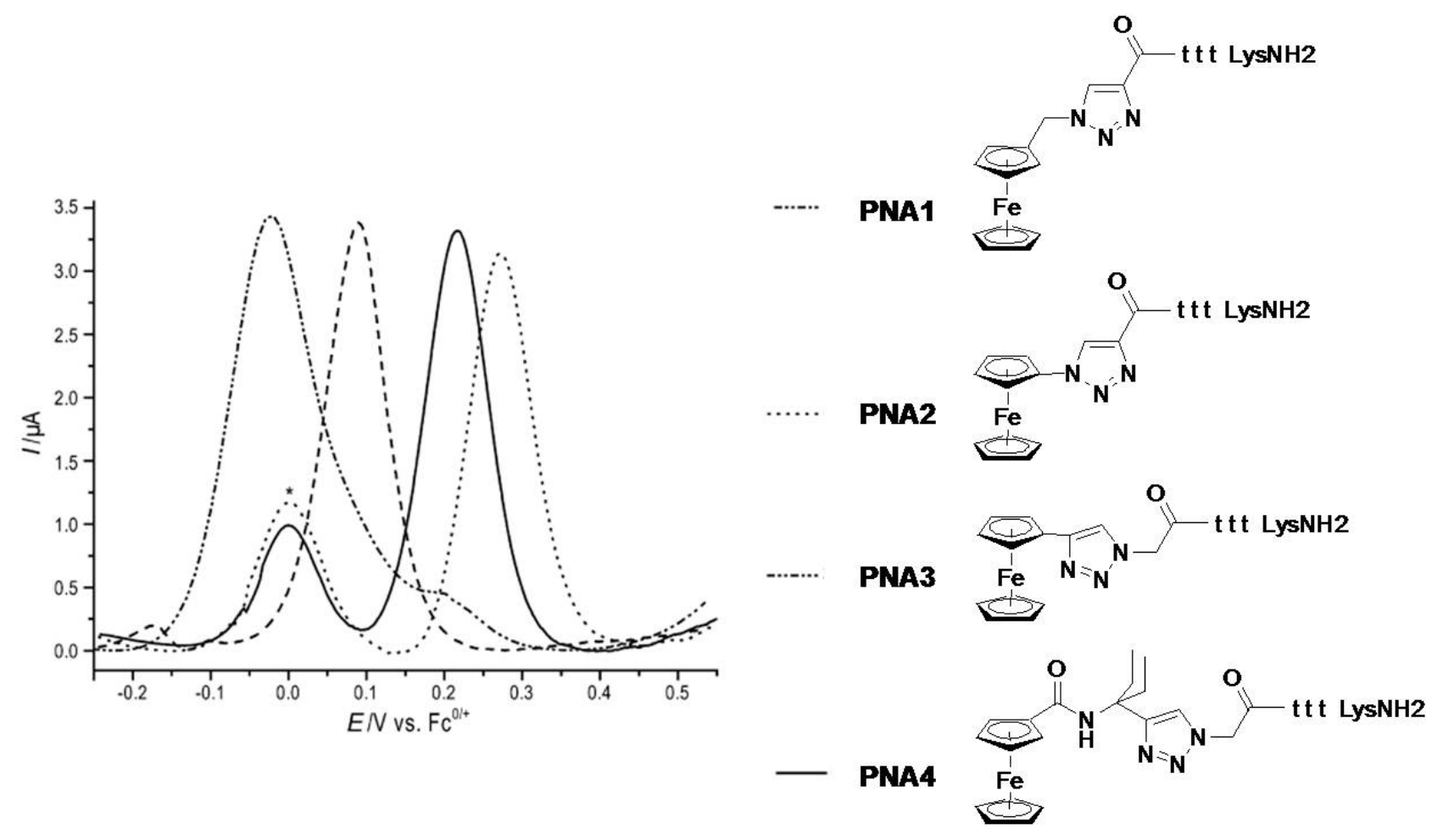

Figure 5. Overlay of differential pulse voltammograms of Fc conjugates of PNA trimers (structures of the Fc-PNAs on the right inside of the figure). The marked signal $\left(^{*}\right)$ at $0.0 \mathrm{~V}$ indicates internal ferrocene as the standard. Adapted from reference. ${ }^{58}$

Recently, a dual-potential Fc-PNA biosensor was reported, which is able to identify two different DNA target sequences on one biosensor surface in one square wave voltammetry (SWV) experiment. ${ }^{59}$ This biosensor discriminates not only single-nucleotide polymorphism (SNP) sequences but is also compatible with biological samples, which is promising for real-life applications.

Nucleobases in PNA monomers were also replaced by redox-active Ru(II) complexes with various linkers in view of direct and specific insertion of these modified monomers in PNA sequences. ${ }^{60}$ The preparation of hetero-bi-metallic thymine PNA monomers was reported using chemically selective reactions at two different sites of the monomer, i.e. ferrocene at the $N$ - and a bis(triphenylphosphine)platinum(0) group at the $C$-terminus (3, Figure 6). ${ }^{61}$ Recently, a hetero-triorganometallic PNA monomer with a cymantrene moiety at the $N$-terminus, a Re-tricarbonyl moiety at 
the $C$-terminus and a "clicked" ferrocene replacing the nucleobase (4, Figure 6) was described for combined multiple application in electrochemical, spectroscopic and bio-imaging field. ${ }^{62}$
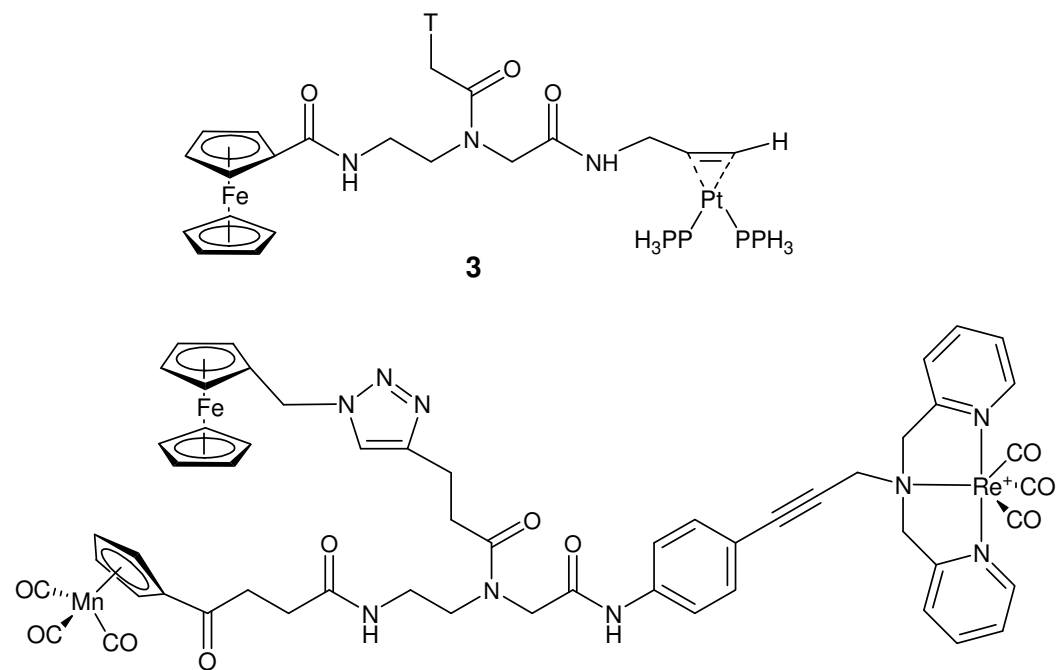

4

Figure 6. hetero-bi-metallic thymine PNA monomer 3 (top) and hetero-tri-organometallic conjugate 4 (bottom).

In view of fluorescence imaging, Licandro, Maiorana and co-workers recently reported the insertion of fluorescent di-rhenium organometallics, namely $\left[\operatorname{Re}_{2}(\mathrm{CO})_{6}(\mu-\mathrm{Cl})_{2}(\mu-4-\mathrm{COOH}-\right.$ pyridazine $\left.)\right]$ and $\left[\mathrm{Re}_{2}(\mathrm{CO})_{6}(\mu-\mathrm{Cl})_{2}\left(\mu-4-\left(\mathrm{CH}_{2}\right)_{3} \mathrm{COOH}-\right.\right.$ pyridazine $\left.)\right]$, to the amino-terminus of a PNA momomer and PNA decamers. In cellular imaging experiments, they determined that one of their Re-PNA bioconjugates could stain both the cytoplasm and the nucleus of HEK-293 cells. ${ }^{63}$ 


\section{Metal-containing PNAs as artificial nucleases.}

The idea of constructing artificial nucleases working as restriction endonucleases or ribonucleases is very appealing. ${ }^{64}$ Indeed, the sequence specific cleavage of DNA or RNA using designed synthetic molecules would be an amazing tool in biochemistry, molecular biology or even as therapeutics. ${ }^{65,66}$ One could imagine, for example, that a specific mRNA could be cleaved and thus suppress the formation of a harmful protein. Furthermore, contrary to restriction endonucleases, which recognise only short oligonucleotide sequences and hence produce many fragments upon cleavage of genomic DNA, ${ }^{67}$ artificial nucleases could potentially cleave any DNA/RNA sequences "upon request".

Artificial nucleases generally incorporate a nucleic acid sequence recognition domain and a functionality, which mediates phosphate diester cleavage (see Figure 7). ${ }^{65}$ For the recognition unit, PNAs are obviously ideal candidates due to the high stability of the PNA $\bullet$ DNA or PNA $\bullet$ RNA duplexes and their resistance to nucleases. It is therefore not surprising that PNAs have been employed for such purposes. These artificial nucleases have been recently described as peptide nucleic acid based artificial nucleases (PNAzymes) ${ }^{66}$ For the "cleaving unit", a metal moiety is usually required although purely organic alternative agents have been used such as neamine or diethylenetriamine. ${ }^{68-71}$ Indeed, the cleavage with artificial metallo-nucleases is following either an oxidative or a hydrolytic mechanism. ${ }^{67}$, 72-74 The former is observed with redox-active metal complexes while the latter one is based on the Lewis-acidity of metal ions. At this point, we emphasise that we will cover only work in which PNAs are covalently linked to a metal complex and act as a recognition fragment for a complementary DNA or RNA sequence. Other interesting approaches by Matsudaira, Komiyama et al., in which the use of a mixture of PNA and metal complex to rapidly, site-selectively hydrolyse double-stranded DNA, is not

included in this perspective. ${ }^{75,76}$ In their work, the PNA acts as a "strand invader" and "protecting group" rather than as a "recognition unit". 


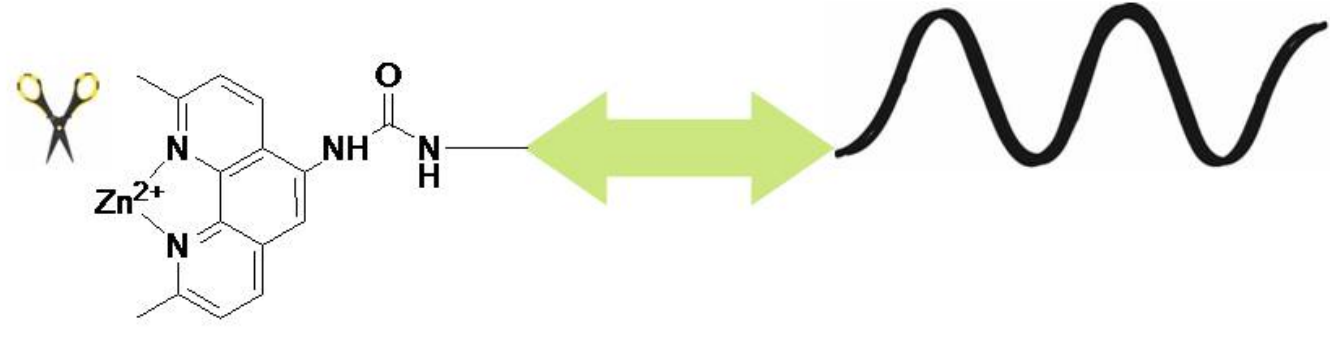

\section{Metallo-Scissor Spacer PNA}

Figure 7. Schematic representation of an artificial nuclease containing a PNA sequence.

To the best of our knowledge, only Nielsen, Meunier and co-workers described the use of metalloPNA for oxidative DNA cleavage. They prepared a cationic manganese porphyrin-PNA conjugate which was used to cleave a double-stranded DNA (dsDNA) (5, Figure 8). ${ }^{77}$ More specifically, upon oxidative activation of $\mathbf{5}$ with potassium monopersulfate to form a manganese-oxo derivative, the sequence specific, 3'-staggered cleavage of both DNA strands near the strand displacement junction of a 247-base pair restriction DNA fragment containg a 10-base pair homopurine binding target for the PNA was observed (estimated yields were $5-10 \%$ at room temperature). ${ }^{77}$ Interestingly, using an electrophoretic mobility shift assay, 5 was found to bind over 100 -fold more strongly to the dsDNA compared to the native PNA. This observation was ascribed to the high affinity of the metalloporphyrin moiety for the minor groove of dsDNA, thus increasing the local concentration of the PNA moiety close to the DNA helix and therefore the probability of duplex invasion. 


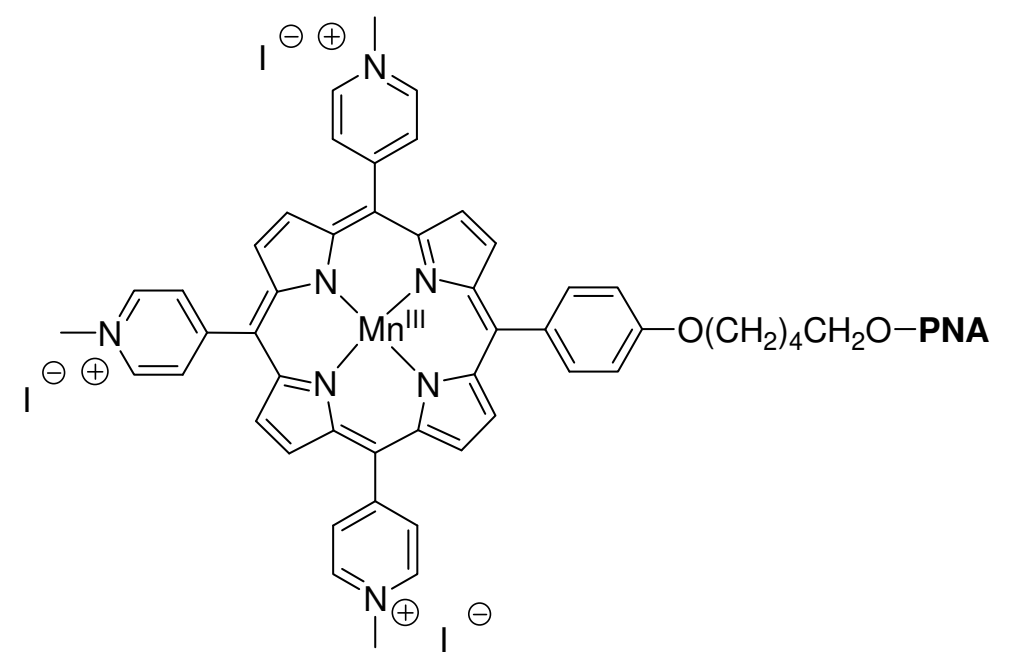

5

Figure 8. Structure of the metalloporphyrin part of the PNA conjugate (5).

A serious drawback of the oxidative cleavage is the generation of products with unnatural termini, whereas the cleaving products of hydrolytical nucleases can be further processed by enzymes. ${ }^{72,73}$ Therefore, the hydrolytic cleavage of linear $\mathrm{DNA}^{67}$ and $\mathrm{RNA}^{65,66,78}$ using PNAzymes is generally preferred. Although most of the examples concern the cleavage of RNA, which is known to be more susceptible to hydrolysis than DNA, ${ }^{74}$ Zelder, Mokhir and Krämer demonstrated that the sequencespecific DNA strand cleavage was possible. ${ }^{67}$ They attached a series of ligands to the $N$-terminus of PNA oligomers and then investigated the cleavage of a DNA strand complementary to their PNA upon addition of $\mathrm{Zr}(\mathrm{IV})$ (see Figure 9). ${ }^{67}$ They found that the activity was strongly dependent on the nature of the chelating ligand and that tris(hydroxymethyl)aminoethane (TRIS) was the most efficient ligand when 10 equivalents of $\mathrm{Zr}(\mathrm{IV})$ was added $\left(76 \pm 19 \%\right.$ DNA cleavage after $164 \mathrm{~h}$ at $\left.22^{\circ} \mathrm{C}\right)$. The DNA phosphodiester groups, which were in close proximity to the terminal PNA modification, were predominantly cleaved. Furthermore, it was shown that the cleavage products were substrates of terminal transferase. However, significant non-selective background cleavage by excess free $\mathrm{Zr}(\mathrm{IV}$ ) was observed in single stranded DNA (ssDNA) whereas the DNA seemed to be protected in the PNA $\cdot$ DNA duplex. This observation highlights the need for chelating ligands which form stronger complexes with 
$\mathrm{Zr}(\mathrm{IV})$ without loss of phosphodiesterase activity. ${ }^{67}$ However, such improvements using $\mathrm{Zr}(\mathrm{IV})$ complexes seems difficult due to the complicated $\mathrm{Zr}(\mathrm{IV})$ chemistry in aqueous conditions. Alternatives using different metal ions are therefore desirable.

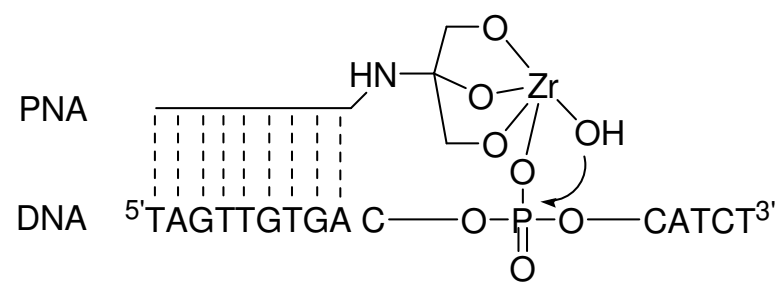

Figure 9. Proposed model for hydrolytic DNA scission by a PNA-Zr(IV) conjugate. Adapted from reference. $^{67}$

Balasubramanian et al. reported the preparation of a neocuprine-PNA monomer (6) and its subsequent insertion within PNA oligomers. ${ }^{65}$ They positioned 6 either at the $N$-terminus $\left(\mathrm{P}_{\mathrm{N} 1}\right)$ or in the middle of a PNA oligomer $\left(\mathrm{P}_{\mathrm{M} 1}\right)$, then added to the two PNAs a complementary 21-mer RNA strand (nucleotides 41 to 61 of the human telomerase - hTR21) to form a PNA $\bullet$ RNA hybrid before adding 2 equivalents of $\mathrm{Zn}(\mathrm{OAc})_{2}$. They observed a site-specific RNA cleavage by both $\mathrm{P}_{\mathrm{M} 1}$ and $\mathrm{P}_{\mathrm{N} 1}$ with a cleavage efficiency of $12 \pm 2 \%$ and $30 \pm 2 \%$, respectively, after $24 \mathrm{~h}$ incubation at $37^{\circ} \mathrm{C}$. When the authors extended their study to a 647-mer (instead of the 21-mer), they observed the same efficiency for $\mathrm{P}_{\mathrm{M} 1}$, within experimental error, as for the short model oligonucleotide target hTR21. An efficiency reduction, however, was observed for $\mathrm{P}_{\mathrm{N} 1}$.

As RNA bulges are more predisposed to cleavage than duplexed RNA, ${ }^{79}$ Strömberg et al. designed PNAzymes to create bulges in the targeted RNA. Thus, they described the preparation of PNA conjugates containing 2,9-diamino-1,10-phenantroline ${ }^{78}$ or 2.9-dimethylphenantroline (neocuproine) ${ }^{66}$ derivatives (see Figure 10 for examples of PNA oligomers 7 and 8). As in Balasubramanian's constructs, they inserted the phenantroline derivatives at the $N$-terminus $\left(\mathrm{P}_{\mathrm{N} 2}\right)$ or at the centre $\left(\mathrm{P}_{\mathrm{M} 2}\right)$ of their PNA sequences. In their first study, involving the use of 2,9-diamino-1,10-phenantroline derivatives, ${ }^{78}$ the results of their cleavage studies involving the addition of 25 equivalents of $\mathrm{Zn}\left(\mathrm{NO}_{3}\right)_{2}$ 
were unanticipated (half-lifes between 43 to 140 hours at $37^{\circ} \mathrm{C}$ ). Indeed, the oligomer with the highest cleavage efficiency and the highest selectivity was found to be a PNA oligomer used as control experiment - a PNA without a 2,9-diamino-1,10-phenantroline derivative. In their next report, involving the cleavage of a RNA strand which was a short model of the leukemia related bcr/abl mRNA, they showed that PNAzymes such as $\mathbf{8}$ could cleave the targeted RNA with a half-life as low as $11 \mathrm{~h}$ (at $37^{\circ} \mathrm{C}$ using 25 equivalents of $\mathrm{Zn}^{2+}$ ). As expected, the scission only took place within the formed bulge with a rate constant up to $17.6 \pm 0.6 \mathrm{~s}^{-1}$ for the fastest system. The most interesting result was that their PNAbased systems could act in a catalytic fashion with turnover of substrate - the first reported PNA-based artificial RNA-cleaving unit. ${ }^{66}$ Very recently, the same authors reported a similar $\mathrm{Cu}(\mathrm{II})$ based system (instead of $\mathrm{Zn}(\mathrm{II})$ ), in which the cleavage takes place at virtually only one site and with a half-life of down to 30 minutes under stoichiometrically-controlled conditions. ${ }^{80}$ In this study, a true enzymatic behaviour was demonstrated when an efficient turnover of RNA substrate was shown with a 100-fold excess of substrate. ${ }^{80}$

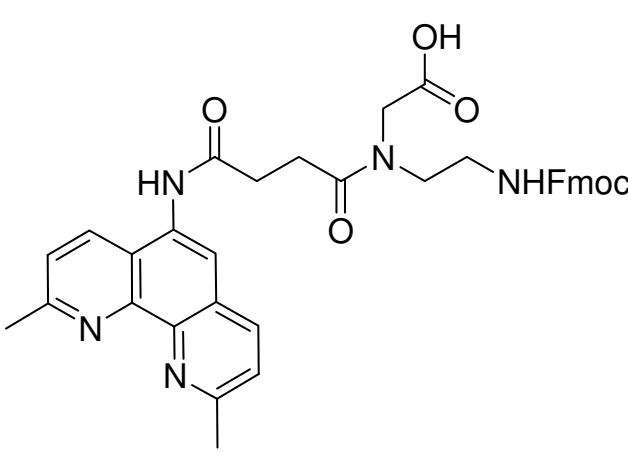

6

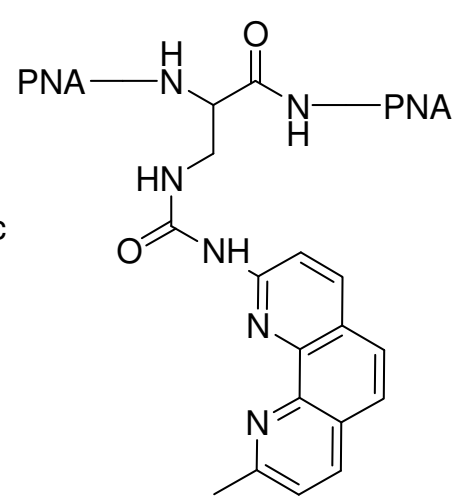

7<smiles>Cc1ccc2cc(NC(=O)NCC(NC#N)C(=O)NC(N)C#N)c3ccc(C)nc3c2n1</smiles>

8

Figure 10. Structures of PNA monomer 6 and of phenantroline-containing PNA- oligomers 7 and 8.

Another interesting approach has been introduced by Panyutin et al., ${ }^{81}$ who reported the sequencespecific DNA strand cleavage by incorporation of the Auger electron-emitting radionuclide ${ }^{111}$ In into PNA oligomers. More specifically, they conjugated diethylene triamine pentaacetic acid (DTPA) to PNA oligomers before chelating them with ${ }^{111} \mathrm{In}^{3+}$ in acidic aqueous solutions. Targeting of ssDNA to 
these PNA-DTPA- $\left[{ }^{111} \mathrm{In}\right]$ yielded highly localized DNA strand cleavage. However, the overall yield of breaks in the PNA-targeted DNA was low (5-7\% after 10-14 days).

Although very attractive on paper, obtaining high catalytic efficiency and specificity is very challenging and the artificial nuclease systems reported to date have been generally too slow for the efficient suppression of gene expression. Nonetheless, these examples provide a good starting point for the development of potential therapeutic agents and the recent finding by Strömberg et al. could at least serve as a basis for construction of RNA restriction enzymes for in vitro manipulations. ${ }^{80}$ 


\section{Metal-containing PNAs as artificial proteases.}

Target-selective artificial proteases are synthetic catalysts that catalyse the hydrolysis of peptide bonds of the target oligopeptides or proteins selectively. ${ }^{82-84}$ Such systems are of high medical interest. If the substrate of a target-selective artificial protease is a disease-related oligopeptide or protein, then the artificial protease can eliminate the activity of the substrate by acting as a peptide-cleaving catalytic drug. Several metal complexes such as $\mathrm{Cu}(\mathrm{II})$ and $\mathrm{Co}(\mathrm{III})$ cyclen complexes showing proteolytic activity have been reported. ${ }^{82,85,86}$ However, they all lacked selectivity - any proteins could be cleaved. To overcome this problem, it has been envisioned to connect such metal complexes to a binding site that recognizes the target protein. Importantly, to suppress cleavage of non-target proteins, the catalytic centre should have very low protein-cleaving activity when not bound to the binding site. ${ }^{87}$ With this in mind, Suh et al. have embarked on a project to construct a combinatorial library of $\mathrm{Cu}$ (II) or $\mathrm{Co}$ (III) complexes of 1,4,7,10-tetraazacyclododecane (cyclen) derivatives containing analogues of PNA. ${ }^{87,88}$ Indeed, since organic functional groups of some proteins are exploited in recognition of nucleobases of nucleic acids, nucleobases of PNAs may be conversely used in the recognition of proteins. ${ }^{87}$ In other words, the PNA was employed as the potential binding site by protein recognition of derivatives of purine. It must be noted that modified nucleobases termed $\mathrm{A}^{*}$ and $\mathrm{T}^{*}$ were used instead of $\mathrm{A}$ and $\mathrm{T}$. $\mathrm{A}^{*}$ and $\mathrm{T}^{*}$ recognize $\mathrm{T}$ and $\mathrm{A}$ respectively, but $\mathrm{A}^{*}$ and $\mathrm{T}^{*}$ do not recognize each other (See Figure 11a for a schematic of the base pairing and Figure $11 \mathrm{~b}$ for the structure of the combinatorial library of cyclen derivatives containing PNA oligomers). ${ }^{89}$ Base pairing among PNA mixtures present in the library can thus be suppressed by using $\mathrm{A}^{*}$ and $\mathrm{T}^{*}$. 

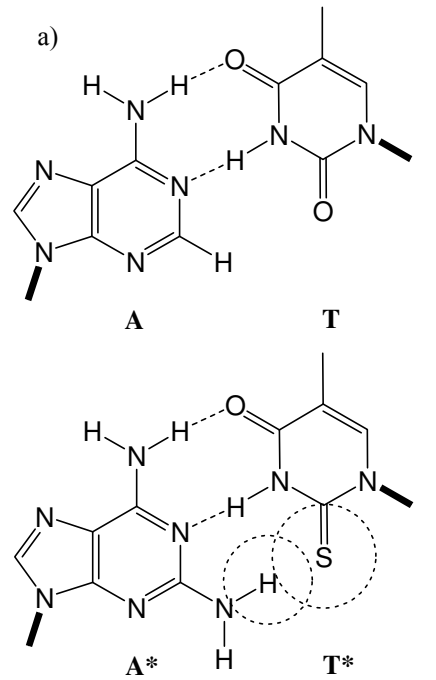
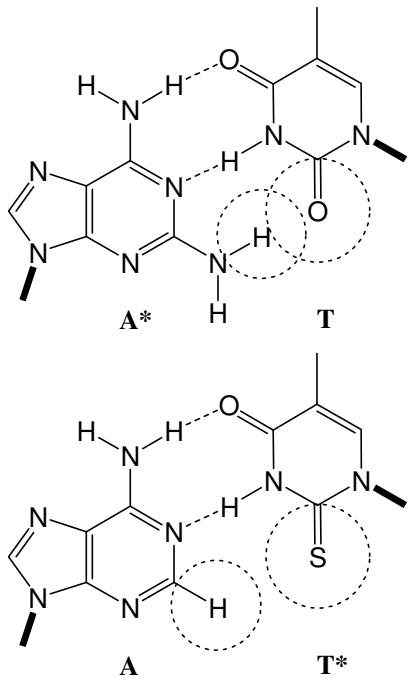

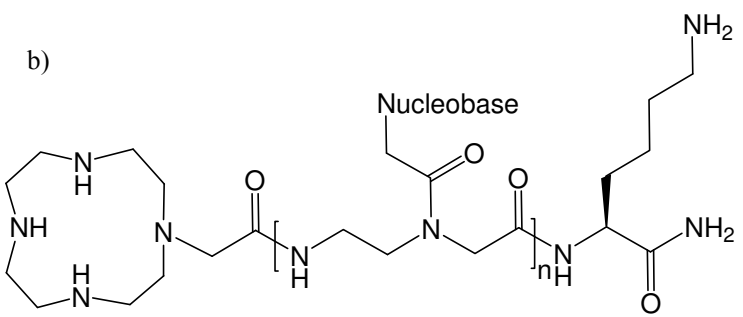

Figure 11. a) Schematic drawing of $A-T, A^{*}-T, A^{*}-T^{*}$ and $A-T^{*}$ base pairs showing how $A^{*}$ can form an extra hydrogen bond with thymine, whereas steric clash occurs between $A^{*}$ and $T^{*} ; b$ ) Structure of the combinatorial library of cyclen derivatives containing PNA oligomers.

Upon complexation of cyclen-containing 7- or 8-mer PNA oligomers with $\mathrm{Cu}(\mathrm{II})$, Shu et al. found no evidence for cleavage of proteins such as bovine serum albumin, $\gamma$-globulin, elongation factor $\mathrm{P}$, gelatine $\mathrm{A}$, gelatine $\mathrm{B}$ and horse heart myoglobin $(\mathrm{Mb})$ at $37^{\circ} \mathrm{C}$ and $\mathrm{pH} 7 .^{87,88}$ However, 9-mer PNAs clearly showed activity for the cleavage of Mb. They also established that the PNA sequence CyclenA*-A*-T*-T*-C-G-A*-A*-C-Lys- $\mathrm{NH}_{2}$ (PNA1) was the best ligand for this particular protein. They also investigated whether other metal ions complexed to PNA1 can cleave Mb and found that $\mathrm{Co}(\mathrm{III})$ displayed the highest protein-cleaving activity. It is noteworthy that $\mathrm{Co}$ (III) complexes may be more suitable for medical uses compared to $\mathrm{Cu}$ (II) complexes since metal transfer to metal-chelating groups in living organisms should be substantially slower for the Co(III) complexes. ${ }^{88}$ Interestingly, kinetic data revealed catalytic turnover of the $\mathrm{Mb}$ cleavage by $\mathrm{Cu}(\mathrm{II})$ and $\mathrm{Co}(\mathrm{III})$ complexes - up to 2.5 or 6 molecules of $\mathrm{Mb}$ were cleaved by each molecule of $\mathrm{Cu}(\mathrm{II})$-PNA1 and $\mathrm{Co}(\mathrm{III})$-PNA1, respectively. ${ }^{87}$ 
These findings are very promising and show that a library of PNAs can be used not only to recognise specific DNA or RNA strands but also to selectively bind a target protein. 


\section{Increase of PNA cellular uptake using metal complexes.}

One of the most important drawbacks in the development of PNAs as potential therapeutic agents is their poor cellular uptake. Hence, for in vitro applications of PNAs for antisense and antigene therapies (see Figure 2), it is required that PNAs enter into cells and that they are properly distributed intracellularly. More specifically, more than one barrier has to be crossed: the plasma membrane of the cell and other intracellular membranes (endosomes, mitochondria, nucleus, etc.). Delivery methods, which are well established for DNA or RNA transfection across cell membranes (electroporation, use of transfection agents, etc.), are not suitable in the same way for the uncharged or weakly cationic PNA oligomers.

The conjugation of cell-penetrating peptides (CPPs) to PNA is a developing strategy with promising results. CPPs are short, cationic and amphipathic peptides, which are able to translocate rapidly into mammalian cells. They have already been used to transport peptides, proteins, oligonucleotides and, more recently, PNAs into cells. Up to now, numerous studies were undertaken not only with the aim to get more insight into the transport mechanisms of CPP-PNA conjugates but also for improved understanding of the nature of CPPs that can be employed. ${ }^{90-93}$ The conjugation to CPPs was found to efficiently improve cell penetration of PNAs. However, the cellular uptake was usually dominated by an endosomal pathway with poor endosomal escape. The PNA conjugates were trapped in endosomes and were not able to distribute evenly into the cytoplasm or to be transported into the nucleus. New strategies for bioavailability such as conjugation to lipid domains ${ }^{94}$ or oligophosphonates ${ }^{95}$ were developed. Another novel and versatile idea is the use of metal complexes to increase cellular uptake. Metal complexes were not only employed to enhance cell penetration and to improve endosomal escape, but also to complete or even replace fluorescent markers for more comprehensive studies. Modification of PNA oligomers with terpyridine (tby) (Fig.12, left) led to cellular and nuclear uptake of conjugates, which was further enhanced by coordination of $\mathrm{Zn}(\mathrm{II})$. Intracellular distribution was shown to be similar in conjugates with different fluorescence agents and also not affected by the addition of zinc. 
Interestingly, since zinc is highly tissue-specific, its addition enables stimulus-controlled cell penetration and might lead to an increased uptake of the PNAs in zinc-rich tissues. ${ }^{96}$

Metzler-Nolte et al. synthesised cobaltocenium conjugates of a NLS (nuclear localization signal) peptide, which are taken up by endocytosis, released efficiently into the cytoplasma and accumulate in the nucleus. $^{97}$ Building on this concept, thymine PNA monomers were modified with dicobalthexacarbonyl derivatives and the preparation of cobalt-containing PNA oligomers is now in progress. ${ }^{98}$

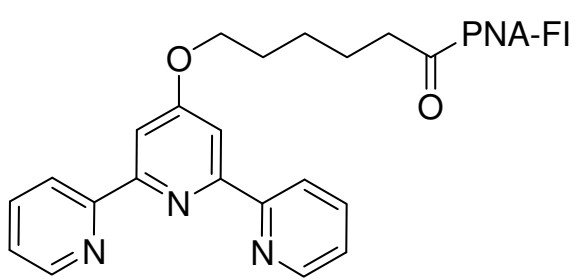

9

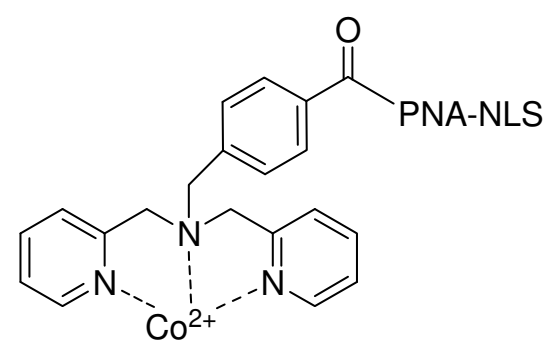

10

Figure 12. left: tby-modified PNA bioconjugates with $C$-terminal fluorophore FI. Right: Cobaltcontaining PNA-NLS bioconjugate.

The presence of a $[\mathrm{Co}(\mathrm{bpa})]^{2+}$ derivative into the PNA-NLS bioconjugate (Figure 12, right, bpa: bispicolylamine) avoids the insertion of a fluorophore. ${ }^{99}$ Cobalt is indeed detectable by AAS (atomic absorption spectroscopy), whose background noise in cells is low. Moreover, in contrast to fluorescence microscopy, AAS is a more direct and sensitive detection method, which makes absolute quantification of cellular uptake straight forward. In addition, as fluoroscent dyes are known to have a major impact on the cellular distribution of conjugates, ${ }^{100}$ the incorporation of a metal complex instead of a fluorescent dye was therefore theorised to solve this problem. Nevertheless, AAS requires the lysis of the cells and compartments, which means that monitoring is not possible in real-time. However, this study showed 
that NLS conjugates containing a metal complex exhibited an enhanced cellular uptake in contrast to metal-free NLS conjugates. This observation is also true for cobaltocenium-NLS conjugates. ${ }^{97}$ It appears that the metal complex improves the properties of the NLS peptide. It facilitates cellular uptake and once within the cytoplasm of the cell, NLS guides the bioconjugate into the nucleus. This was also confirmed in studies with ferrocene and cobaltocene bioconjugates of a NLS peptide. ${ }^{101}$ Furthermore, cellular uptake, endosomal escape and nuclear localisation are not influenced by the charge of the organometallic moiety and no cytotoxic oxidation of the ferrocene takes place within the cells.

PNA-CPP and cholesterol-PNA conjugates with Gd-DOTA were synthesised for magnetic-resonance imaging (MRI). ${ }^{102-104}$ Here, the focus was put on the synthesis of non-toxic, cell-internalizing and contrast-enhancing MR agents as well as mRNA targeting, rather than on the influence of the metal complex on the cellular uptake efficiency and intracellular distribution. In conclusion, the application of metal complexes for increased cellular uptake is in its infancy but the initial findings recently reported (see above) are extremely promising. 


\section{Metal-containing PNAs as radioactive probes.}

Due to their attractive properties, notably their resistance towards nuclease and protease degradation and high selectivity towards DNA/RNA recognition, PNAs have logically found applications in nuclear medicine and biology, where they were used as components for designing radioactive probes. ${ }^{105-139}$ In these studies, a PNA oligomer was coupled to a radioactive moiety. In the majority of the cases, a radiometal complex was used although, for example, radioiodine or radiofluorine were also employed in a few studies. In such constructs, the role of the PNA is usually to direct the bioconjugate to a specific messenger RNA (mRNA), which is unique or uniquely over-expressed mRNA in a diseased cell. The function of the radioactive metal complex is to allow imaging to possibly provide information on cellular gene expression patterns and detect molecular changes at relatively early stages. ${ }^{108,}{ }^{140}$ In the majority of these reports, the radiolabelled PNAs were linked to a peptide, as shown schematically in Figure 13. The role of the peptide is to act as a specific cellular receptor and/or as a cellular uptake enhancer. It must be warned, however, that the attachment of peptides can lead to a high amassment of radioactivity in the kidney, as previously observed by Mier et al. ${ }^{138}$ Alternatively or additionally, specific receptors such as antibodies can be appended to the PNA oligomers in order to target specific (e.g. cancer) cells.

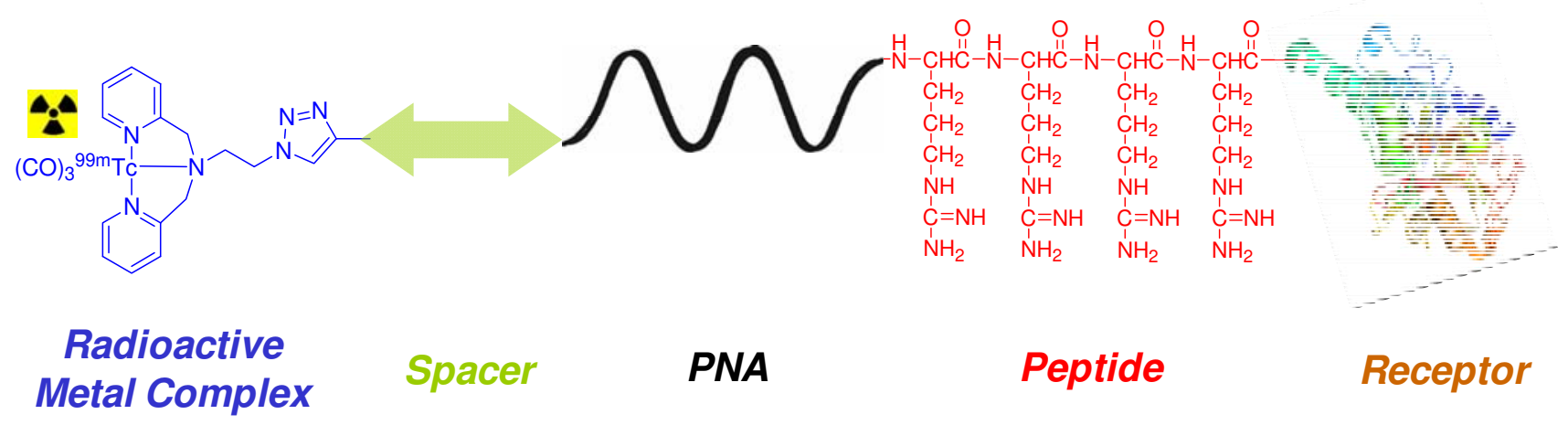

Figure 13. Schematic representation of a radiolabeled PNA. 
In order to get more insight into the pharmacokinetic properties of PNAs, a number of in vivo

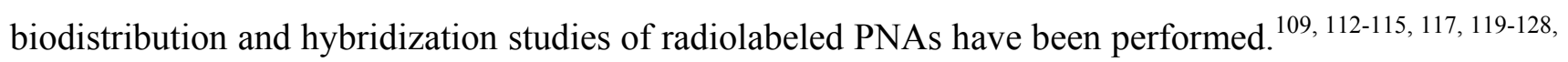
131, 134, 136-139, 141, $142{ }^{99 \mathrm{~m}} \mathrm{Tc}$ has been the most commonly used radioisotope, probably due its ideal radio nuclear properties and the convenient availability from a commercial generator. ${ }^{143-146}$ However, other radio-metals such as ${ }^{64} \mathrm{Cu}$ or ${ }^{111} \mathrm{In}$ have also been employed. Of interest for in vivo pharmacokinetics, our groups recently reported the biodistribution studies of a 12-mer PNA bioconjugate labeled with a tricarbonyl ${ }^{99 \mathrm{~m}}$ Tc complex in Wistar rats. ${ }^{137}$ These investigations showed a fast blood clearance and only a modest accumulation in the kidneys. ${ }^{137}$ Similar results were found when a mouse model (NMRI $\mathrm{nu} / \mathrm{nu})$ was used. ${ }^{137}$

An interesting alternative approach for the use of radioactive PNA probes for therapeutic purposes deserves to be mentioned in this perspective. In the so-called "pretargeting using PNA" developed by Hnatowich et al., ${ }^{120,127,128}$ a single-stranded PNA bound to a protein/antibody - which binds, for example, specifically to receptors over-expressed in cancer cells - is administered first into an animal or human, followed by admission of the complementary single-stranded radiolabeled PNA. This technique provides sufficient time for the protein-PNA conjugate to find its target and, for the excess of the construct, to be cleared from circulation and other tissues. ${ }^{120}$ Nonetheless, there have been, to the best of our knowledge, no other reports since the three papers of Hnatowich and co-workers despite the huge potential and fascinating perspectives of this concept. 


\section{Modulation of PNA・DNA hybrid stability using metal complexes}

The idea to combine the hybridisation properties of PNAs with the coordination properties of a transition metal ion is very appealing. Indeed, this combination could lead to an increase in the thermal stability of PNA $\cdot$ DNA/RNA/PNA hybrids or in the construction of metal-containing nanostructures. The potential applications of these nanostructures are either to expand the genetic code by storing and reading information into a sequence of metal complexes or to create supermolecules with specific magnetic or electronic properties. ${ }^{147}$ With this in mind, Achim and co-workers have inserted up to three consecutive 8-hydroxyquinoline- (11, Figure 14) or bipyridine (bipy)-modified (12, Figure 14) PNA monomers into PNA oligomers. ${ }^{147-150}$ They then examined in detail the interaction of these oligomers with different metal ions and also the stability of duplexes formed from them. In the case of $\mathbf{1 2}$, variable-temperature UV spectroscopy showed that duplexes containing one terminal pair of bipyridine ligands are more stable upon metal binding with $\mathrm{Ni}^{2+}$ and $\mathrm{Cu}^{2+}$ than their non-modified counterparts. ${ }^{147}$ The introduction of a ligand pair situated near the centre of a PNA duplex significantly decreased the duplex's stability in contrast to a modification near the end of the duplex. ${ }^{147}$ Furthermore, the stabilization exerted by metal ions on terminally modified duplexes surpassed the stabilization of duplexes with a central modification. ${ }^{147}$ This difference is the consequence of the base pairs at the end of the duplex being subject to fraying. ${ }^{147}$ The metal-ligand bonds reduce the fraying and significantly stabilize the duplex. ${ }^{147}$ However, the incorporation of multiple $\mathrm{M}^{2+}$-bipy moieties in the centre of a PNA duplex did not grant greater thermal stability, probably because of electrostatic and steric interactions between adjacent, positively charged complexes. ${ }^{147}$ Moreover, UV titrations showed that the presence of several bipy ligands in close proximity to each other in PNA oligomers exerts a chelate effect, which favours the formation of complexes in which the metal ion coordinates the maximum number of accessible ligands. ${ }^{147}$ It is noteworthy that the melting temperatures did not change in the presence of $\mathrm{Pd}^{2+}$ and $\mathrm{Pt}^{2+}$ salts. The authors postulated that the presence of $\mathrm{Cl}^{-}$anions could have transformed the $\left[\mathrm{M}(\text { bipy })_{2}\right]^{2+}$ to $\left[\mathrm{M}(\text { bipy })_{2} \mathrm{Cl}\right](\mathrm{M}=\mathrm{Pd}$ or $\mathrm{Pt}) .{ }^{148}$ 
In the case of 11-containing PNA oligomers, Achim et al. showed by variable-temperature UV-vis spectroscopy that, in the presence of $\mathrm{Cu}^{2+}$, duplexes were formed even from 11-containing strands that have a large number of mismatches. ${ }^{150}$ Spectrophotometric titrations demonstrated that, at any temperature, one $\mathrm{Cu}^{2+}$ ion binds a pair of 11-containing PNA strands that each contained one 8hydroxyquinoline group. ${ }^{150}$ All together, their results indicated that strong metal-ligand alternative base pairs significantly diminish the importance of Watson-Crick base pairing for the formation of a stable PNA duplex and led to high mismatch tolerance. ${ }^{150}$ This principle can be used in the construction of hybrid inorganic-nucleic acid nanostructures. ${ }^{150}$

In a similar line of thought, Diederichsen, Meyer and coworkers have reported the insertion of two successive histidines into the central position of various alanyl-PNA oligomers (alanyl-PNAs). ${ }^{151}$ Once hybridised to a complementary alanyl-PNA strand also containing two successive histidines, they found that the addition of $\mathrm{Zn}^{2+}$ significantly enhanced the double-strand stability, thus supporting the coordination of $\mathrm{Zn}^{2+}$ by the histidine-N and the incorporation of the metal ion within the base stack. ${ }^{151}$ However, in contrast to $\mathrm{Zn}^{2+}, \mathrm{Cu}^{2+}$ ions did not induce double-strand formation. The authors suggested that this difference could be explained by the different geometric preferences of $\mathrm{Zn}^{2+}$ and $\mathrm{Cu}^{2+}$ upon binding to four histidine- $\mathrm{N}$ (tetrahedral for $\mathrm{Zn}^{2+}$, square planar for $\mathrm{Cu}^{2+}$ ). ${ }^{151}$

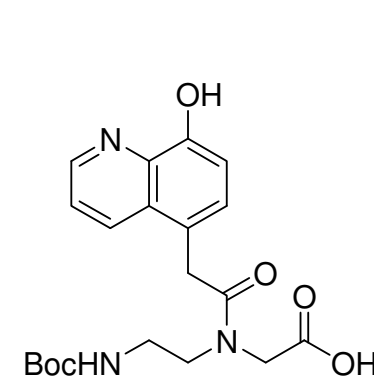

11

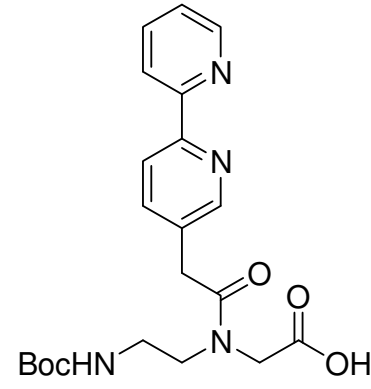

12

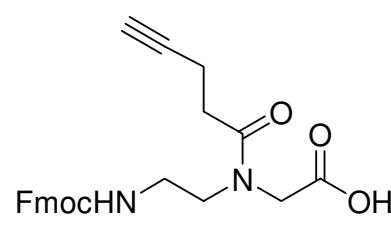

13

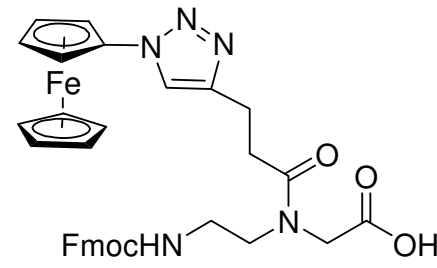

14

Figure 14. Hydroxyquinoline- (11), bipyridine-(12), alkyne-(13) and ferrocene-(14) modified PNA monomers. 
Always in view of understanding the role that metal complexes play for modifying the stability of PNA DNA duplexes, our groups investigated in-depth the role of the insertion of either alkyne-(13) or “clicked" ferrocene ${ }^{57}(\mathbf{1 4})$ - containing PNA monomers into PNA 10mer-sequences on the stability of DNA $•$ PNA hybrids (Figure 14, see also the biosensing section for application of ferrocene-PNA oligomers). ${ }^{152}$ It was demonstrated that modification with alkyne- or ferrocene-containing monomers at the $N$ - or $C$-terminus of the PNA sequence did not significantly alter the thermal stability of DNA $•$ PNA hybrids. These hybrids were considered to be completely complementary due to their similar melting temperatures. This finding showed that the type of modification, namely alkyne- or ferrocene-containing PNA sequences, had no influence on the thermal stability of the hybrids. PNA oligomers, which were extended with one additional modified monomer in their centre (alkyne and ferrocene monomers) hybridised to complementary DNA with melting temperatures $\left(\mathrm{T}_{\mathrm{m}} \mathrm{s}\right)$ of about $51^{\circ} \mathrm{C}$. In contrast, DNA oligomers, which were extended by an additional thymine in the middle of the sequence, formed even more stable hybrids with non-extended PNA sequences. Their $\mathrm{T}_{\mathrm{m}}$ was about $61^{\circ} \mathrm{C}$. All together, these differences observed in the thermal stabilities suggested the formation of a loop out of the extended strand in order to ensure maximal base-pairing in the remaining oligomers (Figure 15). Loop formation is energetically easier accommodated in the DNA strand than in the PNA oligomers because of the more flexible DNA backbone. The findings described in this study show that organometallics such as ferrocene, which are known to be stable, can actually be used to considerably destabilise a DNA $•$ PNA hybrid if "clicked" at the middle of a PNA sequence. This observation is of interest for a potential on/off antisense/antigene strategy. Furthermore, the presence of a metal within a PNA oligomer enables us to quantify its cellular uptake using atomic absorption spectroscopy, as recently demonstrated by our group with a cobalt complex attached to different PNA oligomers. ${ }^{153}$ 


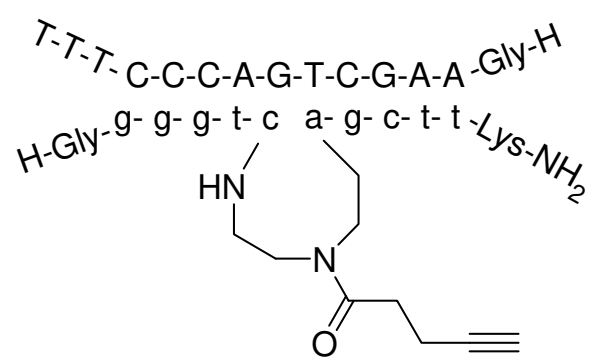

$\mathrm{T}_{\mathrm{m}}=52.4^{\circ} \mathrm{C}$

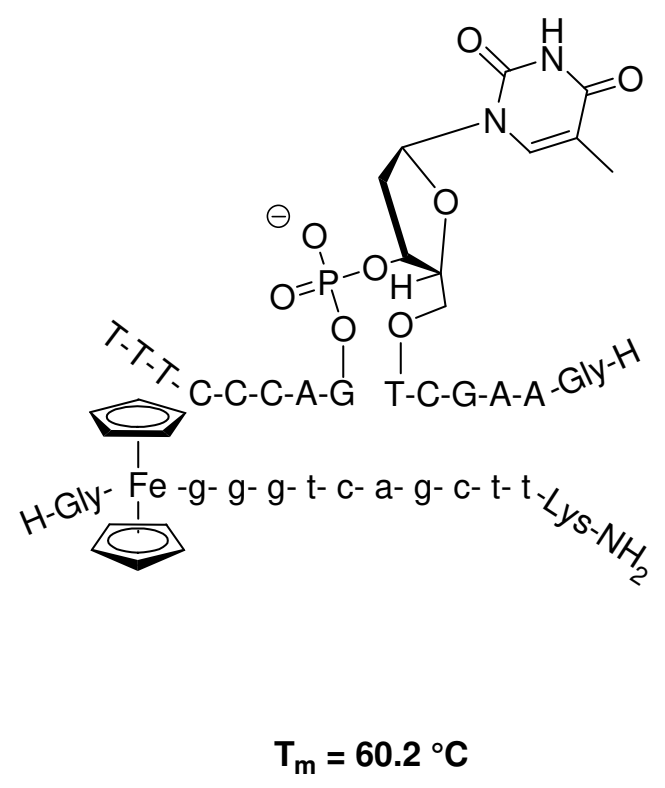

Figure 15. Loop formation in different PNA•DNA hybrids. ${ }^{152}$ Adapted from reference. ${ }^{152}$

Mokhir, Krämer and coworkers proposed to control the PNA binding to oligonucleotides with bioavailable metal ions. Indeed, since the intracellular concentration of free transition metal ions is dependent on the cell type, ${ }^{154}$ metal-responsive PNA $\cdot$ DNA/RNA binding could be employed for selective suppression of gene expression in these specific cells. ${ }^{155}$ For instance, $\mathrm{Zn}^{2+}$ is present at high concentration in the brain, ${ }^{156}$ pancreas ${ }^{157}$ and in spermatozoa. ${ }^{158}$ In breast cancer tissues, zinc levels are increased by $72 \% .{ }^{159}$ With this in mind, bi- and tri-dentate ligands capable of forming $1: 1$ complexes with $\mathrm{Zn}^{2+}, \mathrm{Cu}^{2+}$ and $\mathrm{Ni}^{2+}$ were attached to the $\mathrm{N}$-terminus of PNA oligomers. Thus, the metal complexes with these ligands have free coordination sites which can enable direct coordinative interaction of the metal ion with $\mathrm{N}$-atoms of DNA nucleosides or O-atoms of phosphodiester groups of the DNA backbone. ${ }^{155}$ They observed that the stability of bis(pyridin-2-ylmethyl)amine (dpa)-PNA conjugates and DNA could be significantly modulated by equimolar concentrations of metal ions with an increase of the $\mathrm{T}_{\mathrm{m}} \mathrm{s}$ up to $7^{\circ} \mathrm{C}$ in the order: $\mathrm{Ni}^{2+}, \mathrm{Zn}^{2+}>\mathrm{Cu}^{2+}$. Interestingly, such results were only observed with dpa derivatives but not with other ligands such as (2-pyridyl)-4-pyrimidine or (2-pyridyl)-1H-3pyrazole. These observations were explained by a possible better stabilisation of the PNA $\cdot$ DNA duplex 
by $\mathrm{Ni}^{2+}$ and $\mathrm{Zn}^{2+}$ as a consequence of less hindered coordinative interaction of these metal ions with the phosphodiester groups of the backbone of the target DNA (see Figure 16a). This assumption was reinforced when the authors determined that the $\mathrm{Ni}^{2+}$-induced stabilisation decreased significantly upon addition of $\mathrm{NaCl}$, reflecting the relevance of electrostatic interaction for duplex stabilisation. ${ }^{155}$ In another study, the same authors prepared PNAs to which a $\mathrm{Zn}^{2+}$ chelating ligand (dpa and cyclam) was conjugated via an aromatic linker, namely an unsymmetrically modified naphthalene diimide (NADI) ${ }^{160}$ NADI intercalates into PNA DNA duplexes and strongly stabilises them. ${ }^{161,162}$ As expected for the NADI-Zn(dpa)-containing PNA oligomers, an increase of the duplex stability by cooperative binding of NADI (by intercalation) and the metal complex (by metal coordination) occured (Figure 16b) ${ }^{160}$ In other words, NADI-PNA and Zn(dpa)-PNA did not bind as strongly to the corresponding DNA. They also found that the binding of a cyclam-containing PNA was independent of the $\mathrm{Zn}^{2+}$ concentration. This was explained by the fact that cyclam is doubly protonated at $\mathrm{pH}=7$. Therefore, the electrostatic interactions between the negatively charged DNA and the PNA did not change upon addition of divalent cations such as $\mathrm{Zn}^{2+}$, leading to very similar $\mathrm{T}_{\mathrm{m}} \mathrm{s} .{ }^{160}$
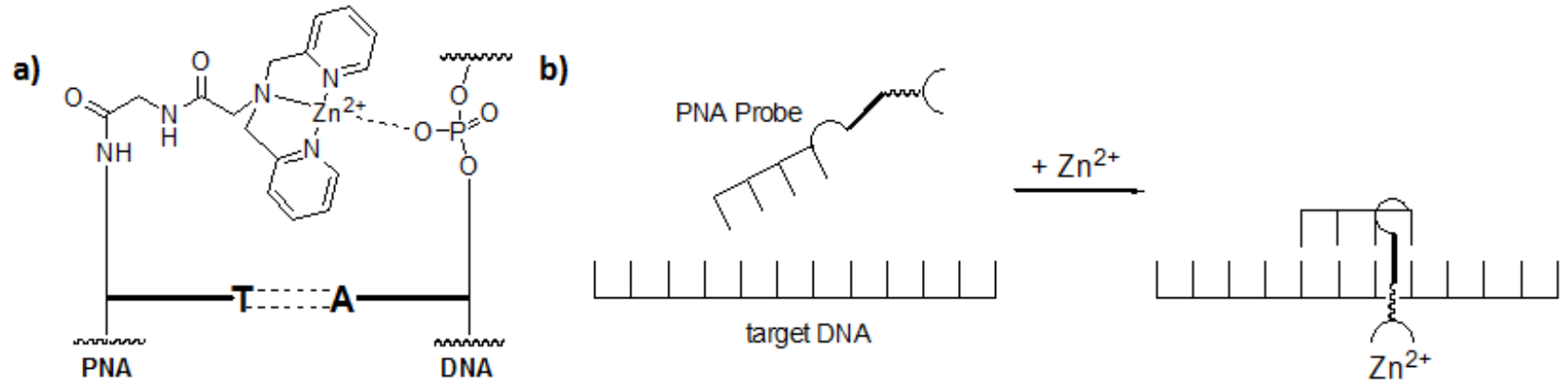

Figure 16. a) Proposed approach for metal-binding of Zn-dpa probes to oligonucleotide targets; b) $\mathrm{Zn}^{2+}$-dependent binding of PNA probes to target DNA. NADI intercalator is shown as a thick line. Adapted and modified from references. ${ }^{155,160}$

In order to modulate the thermal stability of PNA•DNA/RNA duplexes, Gasser, Spiccia, Graham and co-workers investigated the possibility of using artificial nucleobases. ${ }^{163}$ In their study, an adenine 
monomer in a PNA sequence was replaced with a $\mathrm{Zn}(\mathrm{II})$-cyclen. ${ }^{163} \mathrm{Indeed}, \mathrm{Zn}(\mathrm{II})$-cyclen (cyclen $=$ 1,4,7,10-tetraazacyclododecane) complexes were originally shown by Kimura et al. to strongly bind thymidine $(\mathrm{dT})$ in aqueous solution at physiological $\mathrm{pH} .{ }^{164,}{ }^{165}$ In the $1: 1$ adducts, the nucleobase binds to $\mathrm{Zn}(\mathrm{II})$ via the deprotonated imide, and is hydrogen-bonded to the cyclen macrocycle (Figure 17a). The authors were hoping that their artificial base would bind a thymine base (or uracil in RNA) of the complementary DNA/RNA sequence and hence lead to an increase in the stability of their PNA $\cdot$ DNA/RNA duplexes. Furthermore, they postulated that the positive charge brought by the $\mathrm{Zn}(\mathrm{II})$ ion could lead to an increase of the cellular uptake of the modified PNA, as previously reported by Krämer et al. for a PNA Zn(II)-terpyridine conjugate. ${ }^{166}$ With this in mind, they reported the synthesis of a series of cyclen and dpa derivatives, their subsequent attachment to the 5'-amino end of 12-mer PNA sequences complementary to the bulge region of the HIV-1 TAR stem loop RNA (Figure 17b). ${ }^{163}$ Thermal denaturation experiments were performed with a small oligonucleotide transcript of the TAR sequence and some single stranded RNA and DNA oligonucleotides, both in the presence and absence of $\mathrm{Zn}(\mathrm{II})$ ions. They showed that the introduction of cyclen or dpa ligand arms into the PNA constructs leads to a small but reproducible increase in the thermal melting points attributable to hydrogen bonding and/or electrostatic interactions between protonated forms of cyclen/dpa and the cognate RNA or DNA oligonucleotide target. However, contrary to expectations, the addition of $\mathrm{Zn}(\mathrm{II})$ ions did not further enhance duplex stability through binding of $\mathrm{Zn}(\mathrm{II})$-cyclen or $\mathrm{Zn}$ (II)-dpa moieties to the complementary RNA or DNA. A series of native gel-shift assays further confirmed the stability increase of the metalfree cyclen- and dpa-modified PNA hybrids as compared to a control PNA sequence. 


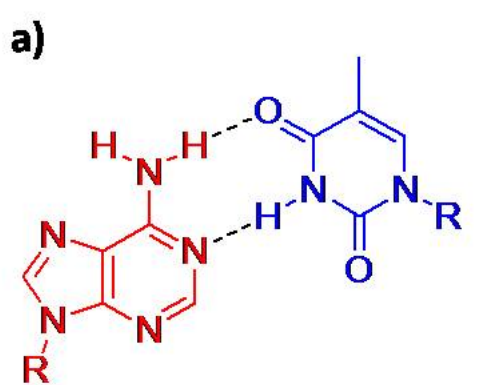

A-T Watson-Crick

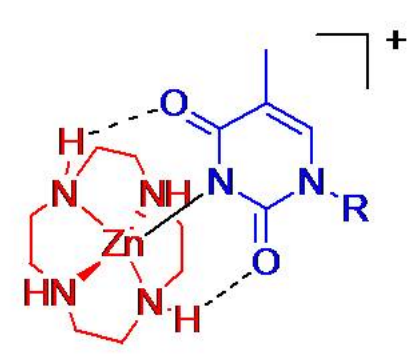

Zn(II) cyclen - T

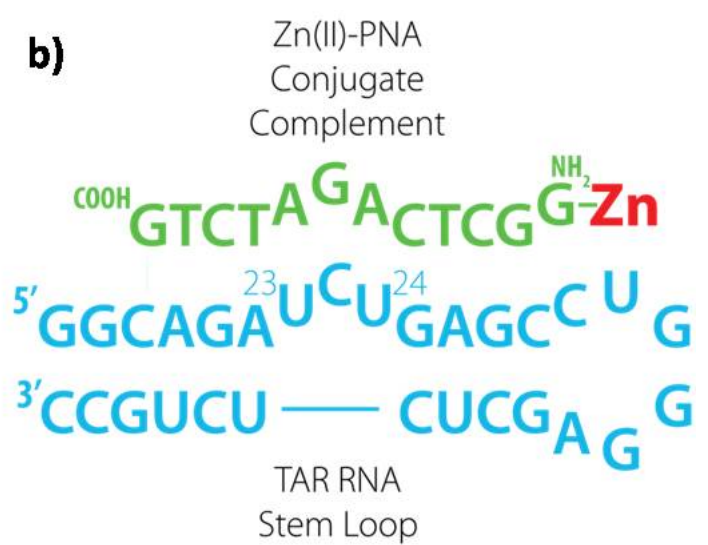

Figure 17. a) Comparison of the canonical Watson-Crick A-T pair with the 'Kimura' Zn(II)-cyclen-

$\mathrm{T}$ pair; b) Design of a Zn(II)-cyclen bearing PNA conjugate targeting a complementary RNA sequence within the bulge region of the HIV-1 TAR stem loop; Zn-cyclen (Red) targets a Uracil partner. Adapted from reference. ${ }^{163}$ 


\section{Metal-containing PNAs as oxidative cross-linkers to a DNA target.}

Cross-links are mediated by agents that form covalent bridges between two different positions within a DNA/PNA strand (intrastrand cross-link) or within two different DNA/PNA strands (interstrand crosslink). ${ }^{167,} 168$ In vivo interstrand cross-links prevent strand separation, leading potentially to inhibition of replication and ultimately to cell death. It is noteworthy that nucleobases, which are damaged by exogenous agents and which are not repaired efficiently can induce apoptosis. Indeed, the toxic effect of many anticancer drugs is based on DNA intra- and interstrand cross-linking (at unspecific sites). ${ }^{167,} 168$ To the best of our knowledge, Burrows et al. are the only researchers, who reported an oxidative crosslinking between a metallopeptide-PNA conjugate and a complementary DNA strand. ${ }^{169}$ In comparison, papers describing interstrand cross-linking between DNA strands are numerous. ${ }^{170-173}$ In Burrows' work, the cross-linking of a PNA to a DNA was mediated by a Ni(sal-XH) motif ( $\mathrm{X}=$ primary aminecontaining $\alpha$-amino acid, e.g. arginine), which was conjugated via a glycine to the $N$-terminus of a PNA oligomer (Figure 18). ${ }^{169}$ While the peptide-PNA fragment was synthesised by standard SPPS protocols, the formation of the complete Ni(sal-RH) motif with bis-(salicylaldehyde)nickel(II) could be prepared either before or after DNA hybridization. The arginine forms an imine bond with the salicylaldehyde to give the planar Ni(II) complex (Schiff-base metallopeptide hybrid). ${ }^{174}$ The coupling of the phenolic oxygen of the salicylaldehyde to DNA was mediated by $\mathrm{KHSO}_{5}$ oxidation via a phenol radical. In this case, the role of the PNA was to bring the DNA bases in close proximity to the complex. This close proximity enhanced the reactivity of the phenol radical towards cytosine and thymine bases as compared to cross-linking of the Ni(sal-RH) motif without the PNA strand, although the guanosine bases remained the most reactive species. Further oxidation with piperidine favours strand scission at the sites of crosslinking. As reported in former studies, the metal complex could be removed by treatment with EDTA resulting in the ready hydrolysis of the Schiff base linkage. ${ }^{174}$ The remaining salicylaldehyde-containing DNA strand could be further functionalized (biotinylation, fluorescently labeled or cross-linked to peptides and proteins). 


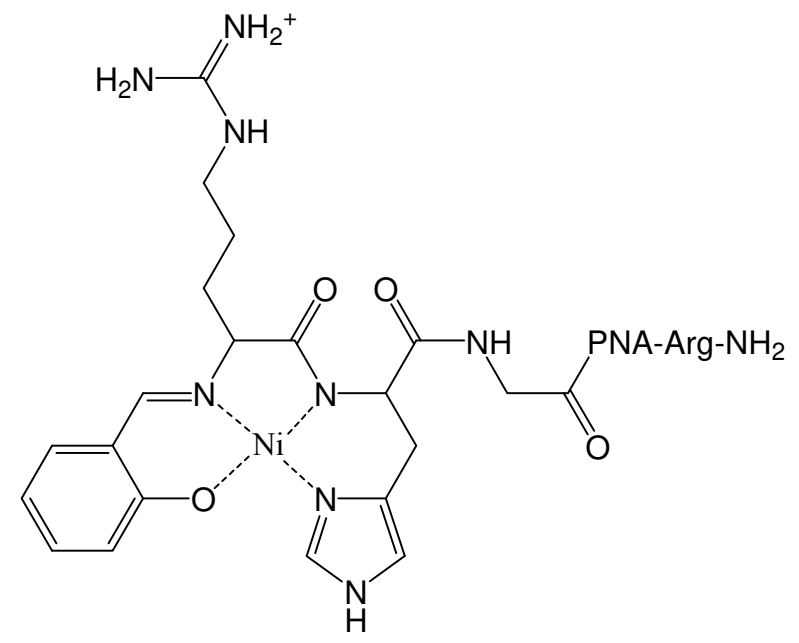

Figure 18. Ni(sal-ArgHis)Gly-PNA conjugate.

It is noteworthy that interstrand cross-links can also be mediated by photolysis. Hong et al. investigated PNA-DNA interstrand cross-linking under oxidative stress and photolysis using phenyl selenidemodified thymines, which were incorporated into a PNA strand. ${ }^{175}$ However, in these examples, no metals were involved. 


\section{Electron-transfer within metal-containing PNA.}

Charge transfer through nucleic acids, especially through DNA, has been investigated and intensely discussed since the 1960s. ${ }^{176,177}$ Charge transport by electron migration in DNA was found to occur efficiently even over long distances. By now, focus has shifted to mechanistic considerations. According to the distance and sequence between charge donors and acceptors in DNA, two theories have been widely accepted. ${ }^{178-180}$ At short distances, charge is transported by a superexchange or tunnelling mechanism in a single coherent jump, in which the rate decreases exponentially with increasing distances and is negligible beyond a few nanometers. For longer distances, charge transport is mediated in an incoherent hopping mechanism. The distance range is influenced by the kinetics of migration and trapping. If the migration rate is fast compared to the trapping rate, the charge transport is more efficient. Hole transfer studies of dsDNA revealed that tunnelling occurs between two guanine bases with a maximal distance of two AT base pairs from each other. No oxidation of these AT base pairs occurs. For three or more AT base pairs between two guanine bases, the mechanism of charge transport converts into hopping through the intervening AT base pairs and adenine bases are oxidized. ${ }^{180}$ The role of guanine and adenine in charge transport is due to their low oxidation/ionisation potentials compared to cytosine and thymine. Due to this, the migration rate via $[\mathrm{A}: \mathrm{T}]$ bridges is faster through adenines than through thymines. In ferrocene-labeled ssDNA, the sequence and length between donor and acceptor plays a minor role in charge transport. Here, the flexibility of the single strand brings electron donor and acceptor close to each other. Demaille, Anne and co-workers investigated the behaviour of Fc-carrying ssDNA and dsDNA layers. ${ }^{181,182}$ In cyclic voltammetry, ssFc-DNA layers are described as diffusionless systems with high flexibility and rapid dynamics. After hybridisation, the voltammetric behaviour is explained by the so-called elastic bending diffusion model. Here, the motion of the redox moiety results from the elastic bending of the double strand toward and away from the electrode surface. This is especially true for short $\mathrm{C}_{2}$ anchoring linkers. ${ }^{183}$ In contrast, Fc-carrying DNA layers, which are attached to the electrode via longer $\mathrm{C}_{6}$ anchoring linkers, allow free rotation of double-stranded layers. 
Thus, charge transfer in Fc-labelled DNA layers is more likely to be mediated via molecular motion than within the strand.

In this context, Achim, Waldeck, Beratan and co-workers investigated the charge transfer occurring in PNAs. More precisely, they studied the role of nucleobases and distance dependence on self-assembled monolayers (SAMs) on gold surfaces of ferrocene-containing ss and dsPNAs. ${ }^{184-186}$ For charge transfer studies, the tunnelling decay constant $\beta$ was measured in SAMs of PNA sequences with varying numbers of thymines (from 3 to 7 thymines) by cyclic voltammetry. ${ }^{186}$ According to the superexchange/tunnelling mechanism, $\beta$ decreases rapidly with increasing PNA length. For more than 7 thymines, the charge transfer rate is less distance dependent, which is consistent with the hopping theory. ${ }^{186}$ Furthermore, the charge transfer rate is sequence-dependent and was found to be slower for ss- $T_{n}-P N A$ than for ss- $A_{n}-P N A$ or than for ds- $(A: T)_{n}-P N A$. The particular influence of the nucleobases in charge transfer for shorter sequences was studied with five different 7-mer PNA sequences containing thymines and a single varying central nucleobase $(\mathrm{G}, \mathrm{A}, \mathrm{C}, \mathrm{T})$ or a central methyl group. ${ }^{184}$ The charge transfer rate $\mathrm{k}_{0}$ was the lowest for a central methyl group and increased with decreasing oxidation potential of the nucleobases. From theoretical studies, charge transfer was shown to occur by superexchange, which is consistent with the observed correlation between charge transfer and oxidation potential. It is noteworthy that Carell and co-workers investigated interstrand excess electron transfer in PNA•DNA hybrids, which did not contain any metal complexes. ${ }^{187}$ 


\section{Metal-containing PNAs for DNA-templated metal catalysis.}

In nature, nucleic acid-templated synthesis is the basis of the development, maintenance and specialisation of life. Enzymes catalyse the synthesis of DNA duplicates (by DNA-templated replication), transport DNA by DNA-templated transcription into RNA and decode the transcripts by RNA-templated translation into regulatory, metabolizing or structural proteins. In this context, Orgel et al. showed the transition between different genetic systems by the non-enzymatic synthesis of PNA from RNA $^{188}$ and $\mathrm{DNA}^{189}$ templates and vice versa. ${ }^{188,190}$ These studies were based on former experiments of DNA-templated DNA synthesis ${ }^{191,192}$ in chemical replication systems. ${ }^{193,}{ }^{194}$ Dervan et al. used duplex DNA templates for non-enzymatic ligation of two pyrimidine oligonucleotides in an initially formed triple helix. ${ }^{195}$ For sequence-specific DNA-targeting applications, Seitz et al. ligated two PNA fragments on a complementary ssDNA, dsDNA and PNA template. ${ }^{196-198}$ Ligation selectivity was further enhanced by the incorporation of abasic sites (glycine, cysteine) at the ligation site.

In an approach to catalyse ester hydrolysis, Kraemer, Mokhir and co-workers attached a $\mathrm{Cu}$ (II) metal complex and the substrate to two different PNA oligomers, which were brought into close proximity at the complementary DNA template (Figure 19). ${ }^{199}$ Elaborate studies were made to optimise the hydrolysis reaction. A $\mathrm{Cu}(\mathrm{II})$ chelating pyridylpyrazolyl group served as the metal complex. Since this ligand forms also stable complexes with $\mathrm{Ni}(\mathrm{II}), \mathrm{Pd}(\mathrm{II})$ and $\mathrm{Zn}(\mathrm{II})$, these metal ions were also tested. ${ }^{200}$ Nonetheless, $\mathrm{Cu}$ (II) was the most efficient metal ion to accelerate the ester hydrolysis (by about 500 times in comparison with its hydrolysis in the absence of the template). Furthermore, picolyl, $N$ methylimidazolyl moieties as well as hydroxyquinoline esterified with benzoic acid were used as substrates to investigate the effect of different $\mathrm{Cu}(\mathrm{II})$ affinities on the reaction yield and turnover. ${ }^{200,201}$ The length of the linker between the ester group and the PNA oligomer was varied from 0-4 atoms with best results observed for a two atom linker, which is explained by an optimal formation of the reactive complex between the metal complex and substrate. ${ }^{199,200}$ 


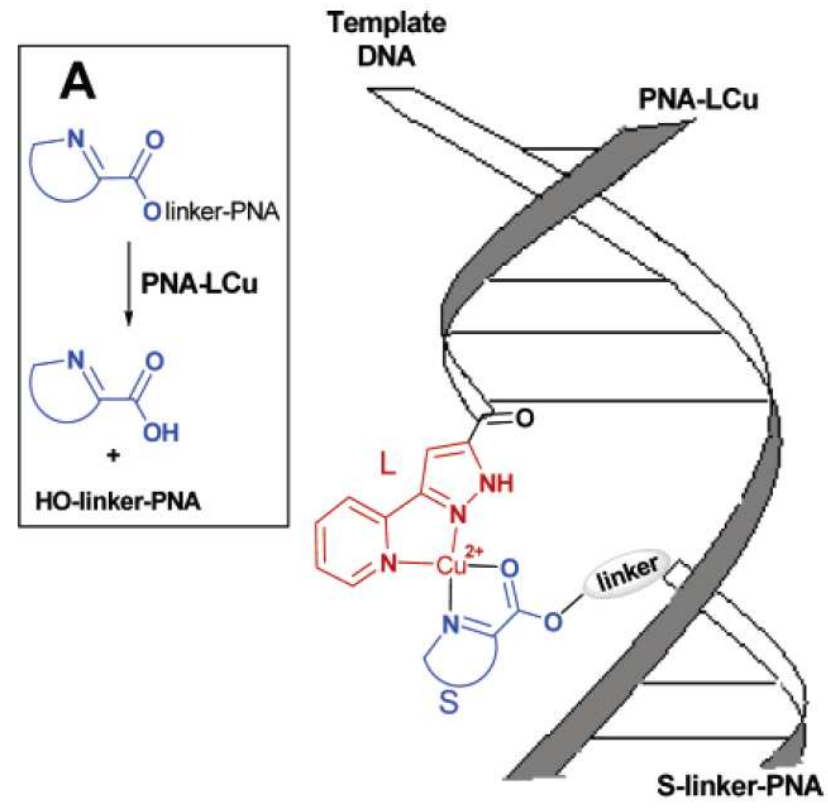

Figure 19. Scheme of a complexed $\mathrm{Cu}$ (II)-ligand-containing PNA (PNA-LCu) and substrate-containing PNA (S-linker-PNA) hybridised to the DNA template. Inset A: DNA-templated, $\mathrm{Cu}(\mathrm{II})$-catalysed ester hydrolysis. Figure reproduced with permission of the publisher from ref. ${ }^{200}$.

Mismatches between the duplexes reduced the cleavage significantly due to the decreased thermal stability between the PNA and DNA strands. ${ }^{199}$ Nevertheless, the exact extent of destabilisation depends on the position of the mismatch. ${ }^{200}$ While a single-mismatch in the substrate-containing PNA $\cdot \mathrm{DNA}$ duplex led to a 7-fold reduction of hydrolysis, a mismatch in the $\mathrm{Cu}(\mathrm{II})$-ligand-containing PNA $\cdot \mathrm{DNA}$ duplex avoided hybridisation and stopped hydrolysis almost completely $\left(>10^{2}\right.$-fold kinetic discrimination between DNA that are different from each other at a single nucleotide position). ${ }^{199,}{ }^{200}$ In comparison, natural enzyme T4 DNA ligase is slightly less selective. ${ }^{200}$

On the basis of this reaction, using MALDI-TOF mass spectrometry, Mokhir et al. developed a fully homogeneous, sensitive assay for the detection of single nucleotide variations in DNA (10 fmol DNA) ${ }^{200}$ In a follow-up study, a DNA duplex was successfully used as a template for sequence-specific ester hydrolysis. ${ }^{202}$ 


\section{Conclusion and Perspective.}

Since the seminal discovery of Watson and Crick that linked the helical structure of double stranded DNA to its function, numerous attempts were made to interfere in a systematic, predictable way with this unique biomolecular structure. The aims of such efforts were either directed towards detection of DNA sequences or the modification of its function. Many DNA analogues that were designed and tested rely on structural motifs that more or less resemble the original phosphate-sugar-nucleobase assembly of DNA (or RNA). Peptide nucleic acids (PNA), discovered in 1991 by Buchardt and Nielsen, present a rather different structure based on peptide chemistry, combined with nucleobase recognition. While PNA offers excellent physicochemical properties, it is still a purely organic molecule and as such, lacks properties that would make a PNA oligomer unique in a biological setting. The addition of metal complexes offers just that uniqueness to PNA oligomers. Features that are added to PNA oligomers by metal complexes include outstanding properties for detection, such as photophysical opportunities, radioimaging, or electrochemical DNA biosensors. Furthermore, chemical functionality may be added to a PNA oligomer through covalent binding of a metal complex, and such conjugates were designed as artificial nucleases or proteases. Finally, the metal complex itself will modify the physicochemical properties of the PNA oligomer, e.g. because of its charge or lipophilicity. Such modifications may be systematically employed for improved or directed cellular uptake of PNA oligomers, to influence duplex stability of PNA•DNA duplices, or to probe DNA or RNA structure.

The above article presents examples for all of the above. The chemical requirements are fairly well understood by now. This extends in particular to the linking of the metal complex to PNA oligomers, which can be performed during the solid phase synthesis cycle of the PNA oligomer, or after cleavage and purification of the PNA oligomer in solution (as, for instance, is mandatory for labelling with radiotracers). More recently, bioconjugation techniques such as "click" chemistry have been successfully employed for this purpose. Having established such a toolbox for the synthesis of metalPNA bioconjugates, there is now ample opportunity for their use in biological studies. Whilst several 
groups are already actively engaged in the field, there is still plenty of room for original ideas and novel approaches. Given the large number and diverse properties of metal complexes, we can certainly expect exciting developments in the area of metal-PNA conjugates in the near future. 
Acknowledgement. The authors thank the Swiss National Science Foundation (Ambizione Fellowship N PZ00P2_126404 to G.G.), the Ruhr-University Research School (fellowship to A.M.S), the Research Department Interfacial Systems Chemistry and the Deutsche Forschungsgemeinschaft (DFG) for funding through the Research Unit "Biological Function of Organometallic Compounds" (FOR 630, www.rub.de/for630/). G.G. thanks Prof. Roger Alberto for generous access to all the facilities of the Institute of Inorganic Chemistry of the University of Zurich. The authors are thankful to Dr. Felix Zelder, Dr. Holger Stephan and Dr. Nina Hüsken for helpful discussions. 


\section{References.}

1. $\quad$ P. E. Nielsen, M. Egholm, R. H. Berg and O. Buchardt, Science, 1991, 254, 1497.

2. P. E. Nielsen and M. Egholm, eds., Peptide Nucleic Acids, Protocols and Applications, Horizon Scientific Press, Wymondham, UK, 1999.

3. K. K. Jensen, H. Orum, P. E. Nielsen and B. Norden, Biochemistry, 1997, 36, 5072.

4. P. Wittung, P. E. Nielsen, O. Buchardt, M. Egholm and B. Norden, Nature, 1994, 368, 561.

5. M. Egholm, O. Buchardt, L. Christensen, C. Behrens, S. M. Freier, D. A. Driver, R. H. Berg, S. K. Kim, B. Norden and P. E. Nielsen, Nature, 1993, 365, 566.

6. P. E. Nielsen, Curr. Opin. Struct. Biol., 1999, 9, 353.

7. U. Koppelhus and P. E. Nielsen, in Antisense Drug Technology, ed. S. T. Crooke, Marcel Dekker, New York, Editon edn., 2001, pp. 359.

8. J. C. Hanvey and L. E. Babiss, in Delivery Strategies for Antisense Oligonucleotide Therapeutics ed. S. Akhtar, CRC Press Inc., Boca Raton, Editon edn., 1995, pp. 151.

9. R. Gambari, Curr. Top. Pharmacol., 2004, 8, 313.

10. S. Cogoi, A. Codognotto, V. Rapozzi and L. E. Xodo, Nucleos. Nucleot. \& Nucleic Acids, 2005, 24, 971 .

11. V. L. Marin, S. Roy and B. A. Armitage, Expert Opin. Biol. Ther., 2004, 4, 337.

12. J. Wang, in Peptide Nucleic Acids, Protocols and Applications, eds. P. E. Nielsen and M. Egholm, Horizon Scientific Press, Wymondham, Uk, Editon edn., 1999, pp. 155.

13. D. Pouchain, J. J. Diaz-Mochon, L. Bialy and M. Bradley, ACS Chem. Biol., 2007, 2, 810.

14. N. Metzler-Nolte, in Bioorganometallics: Biomolecules, Labeling, Medicine, ed. G. Jaouen, Wiley-VCH, Weinheim, Editon edn., 2006.

15. N. Metzler-Nolte and M. Salmain, in Ferrocenes: Ligands, Materials and Biomolecules, ed. P. Stepnicka, John Wiley \& Sons Ltd., Chichester, UK Editon edn., 2008, pp. 499.

16. N. Metzler-Nolte and K. Severin, in Concepts and Models in Bioinorganic Chemistry, eds. H.-B. Kraatz and N. Metzler-Nolte, Wiley-VCH Verlag GmbH \& Co, Weinheim, Germany, Editon edn., 2006, pp. 113.

17. K. M. Millan, A. Saraullo and S. R. Mikkesen, Anal. Chem., 1994, 66, 2943.

18. S. R. Mikkelsen, Electroanalysis, 1996, 8, 15.

19. M. Gębala, L. Stoica, S. Neugebauer and W. Schuhmann, Electroanalysis, 2009, 21, 325.

20. D. Li, Y. Yan, A. Wieckowska and I. Willner, Chem. Comm., 2007, 3544.

21. Y.-T. Long, C.-Z. Li, T. C. Sutherland, H.-B. Kraatz and J. S. Lee, Anal. Chem., 2004, 76, 4059.

22. T. G. Drummond, M. G. Hill and J. K. Barton, Nat. Biotechnol., 2003, 21, 1192.

23. P. A. E. Piunno, U. J. Krull, R. H. E. Hudson, M. J. Damha and M. Cohen, Anal. Chim. Acta, 1994, 288, 205.

24. T. Vo-Dinh, K. Huck and D. L. Stokes, Anal. Chem., 1994, 66, 3379.

25. H. J. Watts, D. Yeung and H. Parkes, Anal. Chem., 1995, 67, 4283.

26. T. Endo, K. Kerman, N. Nagatani, Y. Takamura and E. Tamiya, Anal. Chem., 2005, 77, 6976.

27. S. Cagnin, M. Carabello, C. Guiducci, P. Martini, M. Ross, M. SantaAna, D. Danley, T. West and G. Lanfranchi, Sensors, 2009, 9, 3122.

28. J. Wang, E. Palecek, P. E. Nielsen, G. Rivas, X. Cai, H. Shiraishi, N. Dontha, D. Luo and P. A. M. Farias, J. Am. Chem. Soc., 1996, 118, 7667.

29. J. Wang, Biosens. Bioelectron., 1998, 13, 757.

30. J. Wang, Curr. Issues Molec. Biol., 1999, 1, 117.

31. M. Steichen, Y. Decrem, E. Godfroid and C. Buess-Herman, Biosensors \& Bioelectronics, 2007, 22, 2237.

32. D. Ozkan, A. Erdem, P. Kara, K. Kerman, J. J. Gooding, P. E. Nielsen and M. Ozsoz, Electrochem. Comm., 2002, 4, 796. 
33. K. Hashimoto and Y. Ishimori, Lap on a Chip, 2001, 1, 61.

34. M. S. Hejazi, M. H. Pournaghi-Azar and F. Ahour, Anal. Biochem., 2010, 399, 118.

35. D. Ozkan, P. Kara, K. Kerman, B. Meric, A. Erdem, F. Jelen, P. E. Nielsen and M. Ozsoz, Bioelectrochem., 2002, 58, 119.

36. H. Aoki and H. Tao, Anal. Sci., 2008, 24, 929.

37. H. Aoki and H. Tao, Analyst, 2007, 132, 784.

38. E. Palecek, M. Trefulka and M. Fojta, Electrochem. Commun., 2009, 11, 359.

39. X. Luo, T. M.-H. Lee and I. M. Hsing, Anal. Chem., $2008,80,7341$.

40. T. H. Degefa and J. Kwak, J. Electroanal. Chem., 2008, 612, 37.

41. S. D. Keighley, P. Estrela, P. Li and P. Migliorato, Biosens. Bioelectron. , 2008, 24, 906.

42. P. M. Diakowski and H.-B. Kraatz, Chem. Comm., 2009, 1189.

43. E. Mateo-Marti, C. Briones, C. M. Pradier and J. A. Martin-Gago, Biosens. Bioelectron., 2007, 22, 1926.

44. S. D. Keighley, P. Estrela, P. Li and P. Migliorato, Biosens. Bioelectron., 2008, 24, 906.

45. A. Hess and N. Metzler-Nolte, Chem. Comm., 1999, 885.

46. J. C. Verheijen, v. d. G. A. Marel, v. J. H. Boom and N. Metzler-Nolte, Bioconjugate Chem., $2000,11,741$.

47. A. Maurer, H.-B. Kraatz and N. Metzler-Nolte, Eur. J. Inorg. Chem., 2005, 3207.

48. R. H. E. Hudson, G. Li and J. Tse, Tetrahedron Lett., 2002, 43, 1381.

49. C. Baldoli, S. Maiorana, E. Licandro, G. Zinzalla and D. Perdicchia, Org. Lett., 2002, 4, 4341.

50. C. Baldoli, C. Giannini, E. Licandro, S. Maiorana and G. Zinzalla, Synlett, 2004, 6, 1044.

51. S. Maiorana, E. Licandro, D. Perdicchia, C. Baldoli, B. Vandoni, C. Giannini and M. Salmain, J. Mol. Catal. A: Chem., 2003, 204-205, 165.

52. C. Baldoli, P. Cerea, C. Giannini, E. Licandro, C. Rigamonti and S. Maiorana, Synlett., 2005, 13, 1984.

53. C. Baldoli, C. Rigamonti, S. Maiorana, L. Emanuela, L. Falciola and P. R. Mussini, Chem. Eur. J., 2006, 12, 4091 .

54. G. Gasser, M. J. Belousoff, A. M. Bond and L. Spiccia, J. Org. Chem, 2006, 71, 7565.

55. G. Gasser and L. Spiccia, J. Organomet. Chem., 2008, 693, 2478.

56. V. V. Rostovtsev, L. G. Green, V. V. Fokin and K. B. Sharpless, Angew. Chem. Int. Ed., 2002, 41, 2596.

57. G. Gasser, N. Hüsken, S. D. Köster and N. Metzler-Nolte, Chem. Comm., 2008, 3675.

58. N. Hüsken, G. Gasser, S. D. Köster and N. Metzler-Nolte, Bioconjugate Chem., 2009, 20, 1578.

59. N. Hüsken, M. Gebala, W. Schuhmann and N. Metzler-Nolte, ChemBioChem, 2010, 11, 1754.

60. N. Nickita, G. Gasser, A. M. Bond and L. Spiccia, Eur. J. Inorg. Chem., 2009, 2179.

61. G. Gasser, O. Brosch, A. Ewers, T. Weyhermüller and N. Metzler-Nolte, Dalton Trans., 2009, 4310.

62. M. Patra, G. Gasser, D. Bobukhov, K. Merz, A. V. Shtemenko and N. Metzler-Nolte, Dalton Trans., 2010, 39, 5617.

63. E. Ferri, D. Donghi, M. Panigati, G. Prencipe, L. D’Alfonso, I. Zanoni, C. Baldoli, S. Maiorana, G. D'Alfonso and E. Licandro, Chem. Comm., 2010, 46, 6255.

64. S. I. Kirin, R. Krämer and N. Metzler-Nolte, in Concepts and Models in Bioinorganic Chemistry, eds. H.-B. Kraatz and N. Metzler-Nolte, Wiley-VCH, Weinheim, Editon edn., 2006.

65. A. Whitney, G. Gavory and S. Balasubramanian, Chem. Comm., 2003, 36.

66. M. Murtola and R. Strömberg, Org. Biomol. Chem., 2008, 20, 3837.

67. F. H. Zelder, A. Mokhir and R. Kraemer, Inorg. Chem., 2003, 42, 8618.

68. E. Riguet, S. Tripathi, B. Chaubey, J. Désiré, V. N. Pandey and J.-L. Décout, J. Med. Chem., 2004, 47, 4806.

69. J. C. Verheijen, B. A. L. M. Deiman, E. Yeheskiely, G. A. van der Marel and J. H. van Boom, Angew. Chem. Int. Ed., 2000, 39, 369. 
70. L. Petersen, M. C. de Koning, P. van Kuik-Romeijn, J. Weterings, C. J. Pol, G. Platenburg, M. Overhand, G. A. van der Marel and J. H. van Boom, Bioconjugate Chem., 2004, 15, 576.

71. B. Chaubey, S. Tripathi, J. Désiré, I. Baussanne and J.-L. P. Décout, V.N., Oligonucleotides, 2007, 17, 302.

72. W. K. Pogozelski and T. D. Tullius, Chem. Rev., 1998, 98, 1089.

73. C. J. Burrows and J. G. Muller, Chem. Rev., 1998, 98, 1109.

74. B. N. Trawick, A. T. Daniher and B. J.K., Chem. Rev., 1998, 98, 939.

75. Y. Aiba, M. Mori, Y. Yamamoto and M. Komiyama, Nucleic Acids Symp. Ser., 2005, 49, 277.

76. M. Footer, M. Egholm, S. Kron, J. M. Coull and P. Matsudaira, Biochemistry, 1996, 35, 10673.

77. P. Bigey, S. H. Sonnichsen, B. Meunier and P. E. Nielsen, Bioconjugate Chem., 1997, 8, 267.

78. M. Murtola, D. Ossipov, J. Sandbrink and R. Strömberg Nucleosides, Nucleotides Nucleic Acids, 2007, 26, 1479

79. D. Hüsken, G. Goodall, M. J. J. Blommers, W. Jahnke, J. Hall, R. Häner and H. E. Moser, Biochemistry, 1996, 35, 16591.

80. M. Murtola, M. Wenska and R. Strömberg, J. Am. Chem. Soc., 2010, 132, 8984.

81. Y. He, I. G. Panyutin, A. Karavanov, V. V. Demidov and R. D. Neumann, Eur. J. Nucl. Med., 2004, 31, 837.

82. J. Suh and W. S. Chei, Curr. Opin. Chem.Biol., 2008, 12, 207.

83. J. Suh, Acc. Chem. Res., 2003, 36, 562.

84. W. S. Chei and J. Suh, in Progress in Inorganic Chemistry, ed. K. D. Karlin, John Wiley \& Sons, Inc, USA, Editon edn., 2007, vol. 55, pp. 79.

85. B. Jang and J. Suh, Bull. Kor. Chem. Soc., 2008, 29, 202.

86. B. B. Jang, K.-P. Lee, D.-H. Min and J. Suh, J. Am. Chem. Soc., 1998, 120, 12008.

87. J. W. Jeon, S. J. Son, C. E. Yoo, I. S. Hong and J. Suh, Bioorg. Med. Chem., 2003, 11, 2901.

88. J. W. Jeon, S. J. Son, C. E. Yoo, I. S. Hong, J. B. Song and J. Suh, Org. Lett., 2002, 4, 4155.

89. J. Lohse, O. Dahl and P. E. Nielsen, Proc. Natl. Acad. Sci. U.S.A., 1999, 96, 11804.

90. U. Koppelhus, S. K. Awasthi, V. Zachar, H. U. Holst, P. Ebbesen and P. E. Nielsen, Antisense Nucleic Acid Drug Dev, 2002, 12, 51.

91. N. Bendifallah, F. W. Rasmussen, V. Zachar, P. Ebbesen, P. E. Nielsen and U. Koppelhus, Bioconjugate Chem., 2006, 17, 750.

92. Y. Wolf, S. Pritz, S. Abes, M. Bienert, B. Lebleu and J. Oehlke, Biochemistry, 2006, 45, 14944.

93. Y. Turner, G. Wallukat, P. Säälik, B. Wiesner, S. Pritz and J. Oehlke, J. Pept. Sci., 2010, 16, 71.

94. U. Koppelhus, T. Shiraishi, V. Zachar, S. Pankratova and P. E. Nielsen, Bioconjugate Chem., 2008, 19, 1526.

95. T. Shiraishi, R. Hamzavi and P. E. Nielsen, Nuclear Acids Res., 2008, 36, 4424.

96. A. Füssl, A. Schleifenbaum, M. Göritz, A. Riddell, C. Schultz and R. Krämer, J. Am. Chem. Soc., 2006, 128, 5986.

97. F. Noor, A. Wüstholz, R. Kinscherf and N. Metzler-Nolte, Angew. Chem. Int. Ed., 2005, 44, 2429.

98. G. Gasser, M. A. Neukamm, A. Ewers, O. Brosch, T. Weyhermüller and N. Metzler-Nolte, Inorg. Chem., 2009, 48, 3157.

99. S. I. Kirin, I. Ott, R. Gust, W. Mier, T. Weyhermüller and N. Metzler-Nolte, Angew. Chem. Int. Ed., 2008, 47, 955.

100. C. A. Puckett and J. K. Barton, J. Am. Chem. Soc., 2009, 131, 8738.

101. F. Noor, R. Kinscherf, G. A. Bonaterra, S. Walczak, S. Wölfl and N. Metzler-Nolte, Chem. Bio. Chem., 2009, 10, 493.

102. W. Su, R. Mishra, J. Pfeuffer, K.-H. Wiesmüller, K. Ugurbil and J. Engelmann, Contrast Media Mol. Imaging, 2007, 2, 42.

103. R. Mishra, W. Su, R. Pohmann, J. Pfeuffer, M. G. Sauer, K. Ugurbil and J. Engelmann, Bioconjugate Chem., 2009, 20, 1860. 
104. R. Joshi, R. Mishra, R. Pohmann and J. Engelmann, Bioorg. Med. Chem. Lett., 2010, 20, 2238.

105. E. Wickstrom, M. L. Thakur and E. R. Sauter, in Peptide Nucleic Acids, Morpholinos, and Related Antisense Biomolecules, Molecular Biology Intelligence Unit, eds. C. G. Janson and M. J. During, Landes Bioscience/Kluwer Academic/Plenum Publishers, New York, Editon edn., 2006, pp. 59.

106. A. Mukherjee, E. Wickstrom and M. L. Thakur, Eur. J. Radiology, 2009, 70, 265.

107. E. Wickstrom, X. Tian, N. V. Amirkhanov, A. Chakrabarti, M. R. Aruva, P. S. Rao, W. Qin, W. Zhu, E. R. Sauter and M. L. Thakur, in Antisense Therapeutics, ed. M. I. Phillips, Humana Press, Totowa, Editon edn., 2005, vol. 106, pp. 135.

108. M. R. Lewis and F. Jia, J. Cell. Biochem., 2003, 90, 464.

109. X. Sun, H. Fang, X. Li, R. Rossin, M. J. Welch and J.-S. Taylor, Bioconjugate Chem., 2005, 16, 294.

110. F. Gallazzi, Y. Wang, F. Jia, N. Shenoy, L. A. Landon, M. Hannink, S. Z. Lever and M. R. Lewis, Bioconjugate Chem., 2003, 14, 1083.

111. A. Chakrabarti, M. R. Aruva, S. P. Sajankila, M. L. Thakur and E. Wickstrom, Nucleos. Nucleot. \& Nucleic Acids, 2005, 24, 409.

112. X. Tian, M. R. Aruva, K. Zhang, N. Shanthly, C. A. Cardi, M. L. Thakur and E. Wickstrom, J. Med. Chem., 2007, 48, 1699.

113. X. Tian, M. R. Aruva, W. Qin, W. Zhu, K. T. Duffy, E. R. Sauter, M. L. Thakur and E. Wickstrom, J. Nucl. Med., 2004, 45, 2070.

114. X. Tian, M. R. Aruva, H. R. Wolfe, W. Qin, E. R. Sauter, M. L. Thakur, S. A. Waldman and E. Wickstrom, Nucleos. Nucleot. \& Nucleic Acids, 2005, 24, 1085.

115. X. Tian, A. Chakrabarti, N. V. Amirkhanov, M. R. Aruva, K. Zhang, B. Mathew, C. Cardi, W. Qin, E. R. Sauter, M. L. Thakur and E. Wickstrom, Ann. N.Y. Acad. Sci., 2005, 1059, 106.

116. H. Fang, X. Yue, X. Li and J.-S. Taylor, Nucleic Acids Res., 2005, 33, 6700.

117. P. S. Rao, X. Tian, W. Qin, M. R. Aruva, M. L. Thakur and E. Wickstrom, Nucl. Med. Commun., 2003, 24, 857.

118. C. Xavier, C. Giannini, L. Gano, S. Maiorana, R. Alberto and I. Santos, J. Biol. Inorg. Chem., 2008, 13, 1335.

119. G. Mardirossian, K. Lei, M. Rusckowski, F. Chang, T. Qu, M. Egholm and D. J. Hnatowich, J. Nucl. Med., 1997, 38, 907.

120. M. Rusckowski, T. Qu, F. Chang and D. J. Hnatowich, Cancer, 1997, 80, 2699.

121. N. Shi, R. J. Boado and W. M. Pardridge, Proc. Natl. Acad. Sci. U.S.A., 2000, 97, 14709-14714.

122. H. J. Lee, R. J. Boado, D. A. Braasch, D. R. Corey and W. M. Pardridge, J. Nucl. Med., 2002, 43, 948-956.

123. X. Tian, R. Mohan, W. Qin, W. Zhu, E. R. Sauter, M. L. Thakur and E. Wickstrom, Bioconjugate Chem., 2005, 16, 70-76.

124. F. Jia, S. D. Figueroa, F. Gallazzi, B. S. Balaji, M. Hannink, S. Z. Lever, T. J. Hoffman and M. R. Lewis, J. Nucl. Med., 2008, 49, 430.

125. A. Chakrabarti, K. Zhang, M. R. Aruva, C. A. Cardi, A. W. Opitz, N. J. Wagner, M. L. Thakur and E. Wickstrom, Cancer Biology \& Therapy 2007, 6, 948.

126. X. Tian, M. R. Aruva, P. S. Rao, W. Qin, P. Read, E. R. Sauter, M. L. Thakur and E. Wickstrom, Anal. N.Y. Acad. Sci. , 2003, 1002, 165.

127. Y. Wang, F. Chang, Y. Zhang, N. Liu, G. Liu, S. Gupta, M. Rusckowski and D. J. Hnatowich, Bioconjugate Chem., 2001, 12, 807.

128. F. Chang, T. Qu, M. Rusckowski and D. J. Hnatowich, Appl. Radiat. Isot., 1999, 50, 723.

129. S. Scarfi, M. Giovine, A. Gasparini, G. Damonte, E. Millo, M. Pozzolini and U. Benatti, FEBS Lett., 1999, 451, 264.

130. M. R. Lewis, F. Jia, F. Gallazzi, Y. Wang, J. Zhang, N. Shenoy, S. Z. Lever and M. Hannink, Bioconjugate Chem., 2002, 13, 1176. 
131. M. L. Thakur, X. Tian, N. V. Amirkhanov, A. Chakrabarti, M. R. Aruva, P. S. Rao, W. Qin, W. Zhu, E. R. Sauter and E. Wickstrom, Int. J. Nanomanufacturing, 2004, 19, 98.

132. T. Suzuki, D. Wu, F. Schlachetzki, J. Y. Di, R. J. Boado and W. M. Partridge, J. Nucl. Med. , 2004, 45, 1766.

133. A. Tovar-Salazar, J. Dhawan, A. Lovejoy, Q. A. Liu and A. N. Gifford, Anal. Biochem., 2007, 360, 92.

134. X. Tian, A. Chakrabarti, N. V. Amirkhanov, M. R. Aruva, K. Zhang, C. A. Cardi, S. Lai, M. L. Thakur and E. Wickstrom, Biochem. Soc. Trans., 2007, 35, 72.

135. E. Wickstrom and M. L. Thakur, Biotechnol. Healthcare, 2006, 2, 45.

136. E. Wickstrom, E. R. Sauter, X. Tian, S. Rao, W. Quin and M. L. Thakur, Braz. Arch. Biol. Technol., 2002, 45, 57.

137. G. Gasser, K. Jäger, M. Zenker, R. Bergmann, J. Steinbach, H. Stephan and N. Metzler-Nolte, J. Inorg. Biochem., 2010, 104, 1133.

138. W. Mier, R. Eritja, A. Mohammed, U. Haberkorn and M. Eisenhut, Angew. Chem. Int. Ed., 2003, 42, 1968.

139. R. Hamzavi, F. Dolle, B. Tavitian, O. Dahl and P. E. Nielsen, Bioconjugate Chem., 2003, 14, 941.

140. C. Y. Shiue and S. Eck, in Handbook of Radiopharmaceuticals, eds. M. J. Welch and C. S. Redvanly, Wiley, New-York, Editon edn., 2003, pp. 467.

141. K. C. Younes, R. Boisgard and B. Tavitian, Curr. Radiopharma. Des., 2002, 8, 1451.

142. D. Hnatowich and K. Nakamura, Curr. Opin. Mol. Ther., 2006, 8, 136.

143. T. L. Mindt, H. Struthers, E. García-Garayoa, D. Desbouis and R. Schibli, Chimia, 2007, 61, 725.

144. U. Abram and R. Alberto, J. Braz. Chem. Soc., 2006, 17, 1486.

145. Mark Bartholomä, J. Valliant, K. P. Maresca, J. Babich and J. Zubieta, Chem. Comm., 2009, 493.

146. B. Johannsen and H.-J. Pietzsch, Eur. J. Nucl. Med., 2002, 29, 263.

147. R. M. Franzini, R. M. Watson, G. K. Patra, R. M. Breece, D. L. Tierney, M. P. Hendrich and C. Achim, Inorg. Chem., 2006, 45, 9798.

148. D.-L. Popescu, T. J. Parolin and C. Achim, J. Am. Chem. Soc., 2003, 125, 6354.

149. R. M. Franzini, R. M. Watson, D.-L. Popescu, G. K. Patra and C. Achim, Polym. Prepr., 2004, 45, 337.

150. R. M. Watson, Y. A. Skorik, G. K. Patra and C. Achim, J. Am. Chem. Soc., 2005, 127, 14628.

151. A. Küsel, J. Zhang, M. A. Gil, A. C. Stückl, W. Meyer-Klaucke, F. Meyer and U. Diederichsen, Eur. J. Inorg. Chem., 2005, 4317.

152. A. Sosniak, G. Gasser and N. Metzler-Nolte, Org. Biomol. Chem., 2009, 7, 4992

153. S. I. Kirin, I. Ott, R. Gust, W. Mier, T. Weyhermueller and N. Metzler-Nolte, Angew. Chem., Int. Ed., 2008, 47, 955.

154. R. B. Thompson, D. Peterson, W. Mahoney, M. Cramer, B. P. Maliwal, S. W. Suh, C. Frederickson, C. Fierke and P. Herman, J. Neurosci. Methods, 2002, 118, 63.

155. A. Mokhir, R. Stiebing and R. Kraemer, Bioorg. Med. Chem. Lett., 2003, 13, 1399.

156. C. J. Frederickson, Int. Rev. Neurobiol. , 1989, 31, 145.

157. P. D. Zalewski, S. H. Millard, I. J. Forbes, O. Kapaniris, A. Slavotinek, W. H. Betts, A. D. Ward, S. F. Lincoln and I. Mahadevan, J. Histochem. Cytochem., 1994, 42, 877-874.

158. P. D. Zalewski, X. Jian, L. L. Soon, W. G. Breed, R. F. Seamark, S. F. Lincoln, A. D. Ward and F. Z. Sun, Reprod. Fertil. Dev., 1996, 8, 1097-1105.

159. E. J. Margalioth, J. G. Schenker and M. Chevion, Cancer Biology \& Therapy, 1983, 52, $868-872$.

160. A. Mokhir, R. Kraemer and H. Wolf, J. Am. Chem. Soc., 2004, 126, 6208.

161. A. A. Mokhir and R. Kraemer, Bioconjugate Chem., 2003, 14, 877. 
162. A. Mokhir, B. Zohm, A. Füssl and R. Kraemer, Bioorg. Med. Chem. Lett., 2003, 13, 2489.

163. M. J. Belousoff, G. Gasser, B. Graham, Y. Tor and L. Spiccia, J. Biol. Inorg. Chem., 2009, 14, 287.

164. M. Shionoya, E. Kimura and M. Shiro, J. Am. Chem. Soc., 1993, 115, 6730.

165. S. Aoki and E. Kimura, Chem. Rev., 2004, 104, 769.

166. A. Füssl, A. Schleifenbaum, M. Göritz, A. Riddell, C. Schultz and R. Kraemer, J. Am. Chem. Soc., 2006, 128, 5986.

167. D. M. Noll, T. M. Mason and P. S. Miller, Chem. Rev., 2006, 106, 277.

168. S. R. Rajski and R. M. Williams, Chem. Rev., 1998, 98, 2723.

169. O. Kornyushyna, A. J. Stemmler, D. M. Graybosch, I. Bergenthal and C. J. Burrows, Bioconjugate Chem., 2005, 16, 178.

170. R. A. Luce and P. B. Hopkins, Methods Enzymol., 2001, 340, 396.

171. L. C. Erickson, M. O. Bradley, J. M. Ducore, R. A. G. Ewig and K. W. Kohn, Proc. Natl. Acad. Sci. USA, 1980, 77, 467.

172. S. T. Garcia, A. McQuillan and L. Panasci, Biochem. Pharmacol., 1988, 37, 3189.

173. W. J. Bodell, T. Aida and J. Rasmussen, Mutat. Res., 1985, 149, 95.

174. A. J. Stemmler and C. J. Burrows, J. Am. Chem. Soc., 1999, 121, 6956.

175. Y. Kim and I. S. Hong, Bioorg. Med. Chem. Lett., 2008, 18, 5054.

176. H.-A. Wagenknecht, Charge Transfer in DNA - from mechanism to application, Wiley-VCH, Weinheim, Germany, 2005.

177. H.-A. Wagenknecht, in NanoBioTechnology: Bioinspired Devices and Materials of the Future., eds. O. Shoseyov and I. Levy, Humana Press, Totowa, Editon edn., 2007, pp. 89.

178. B. Giese, Curr. Opin. Chem. Biol., 2002, 6, 612.

179. E. M. Boon and J. K. Barton, Curr. Opin. Struct. Biol., 2002, 12, 320.

180. B. Giese, Annu. Rev. Biochem., 2002, 71, 51.

181. A. Anne, A. Bouchardon and J. Moireux, J. Am. Chem. Soc., 2003, 125, 1112.

182. A. Anne and C. Demaille, J. Am. Chem. Soc., 2006, 128, 542.

183. A. Anne and C. Demaille, J. Am. Chem. Soc., 2008, 130, 9812.

184. A. Paul, S. Bezer, R. Venkatramani, L. Kocsis, E. Wierzbinski, A. Balaeff, S. Keinan, D. N. Beratan, C. Achim and D. H. Waldeck, J. Am. Chem. Soc., 2009, 131, 6498.

185. A. Paul, R. M. Watson, P. Lund, Y. Xing, K. Burke, Y. He, E. Borguet, C. Achim and D. H. Waldeck, J. Phys. Chem. C, 2008, 112, 7233.

186. A. Paul, R. M. Watson, E. Wierzbinski, K. L. Davis, A. Sha, C. Achim and D. H. Waldeck, J. Phys. Chem. B, 2009, DOI: 10.1021/jp906910h.

187. M. K. Cichon, C. H. Haas, F. Grolle, A. Mees and T. Carell, J. Am. Chem. Soc., 2002, 124, 13984.

188. C. Böhler, P. E. Nielsen and L. E. Orgel, Nature, 1995, 376, 578.

189. J. G. Schmidt, L. Christensen, P. E. Nielsen and L. E. Orgel, Nuclear Acids Res., 1997, 25, 4792.

190. J. G. Schmidt, P. E. Nielsen and L. E. Orgel, Nuclear Acids Res., 1997, 25, 4797.

191. T. Inoue and L. E. Orgel, J. Mol. Biol., 1982, 162, 201.

192. T. Inoue, G. F. Joyce, K. Grzeskowiak and L. E. Orgel, J. Mol. Biol., 1984, 178, 669.

193. v. G. Kiedrowski, Angew. Chem. Int. Ed., 1986, 25, 932.

194. T. Li and K. C. Nicolaou, Nature, 1994, 369, 218.

195. K. J. Luebke and P. B. Dervan, J. Am. Chem. Soc., 1989, 111, 8733.

196. A. Mattes and O. Seitz, Chem. Comm., 2001, 2050.

197. A. Mattes and O. Seitz, Angew. Chem. Int. Ed., 2001, 40, 3178.

198. S. Ficht, A. Mattes and O. Seitz, J. Am. Chem. Soc., 2004, 126, 9970.

199. J. Brunner, A. Mokhir and R. Kraemer, J. Am. Chem. Soc., 2003, 125, 12410.

200. I. Boll, R. Krämer, J. Brunner and A. Mokhir, J. Am. Chem. Soc., 2005, 127, 7849.

201. F. H. Zelder, J. Brunner and R. Krämer, Chem. Comm., 2004, 902. 
202. I. Boll, E. Jentzsch, R. Krämer and A. Mokhir, Chem. Comm., 2006, 3447. 